\title{
Interaction between hydrocarbon seepage, chemosynthetic communities, and bottom water redox at cold seeps of the Makran accretionary prism: insights from habitat-specific pore water sampling and modeling
}

\author{
D. Fischer ${ }^{1}$, H. Sahling ${ }^{1}$, K. Nöthen ${ }^{2}$, G. Bohrmann ${ }^{1}$, M. Zabel ${ }^{1}$, and S. Kasten ${ }^{1,2}$ \\ ${ }^{1}$ MARUM - Center for Marine Environmental Sciences and Department of Geosciences, University of Bremen, \\ Klagenfurter Strasse, 28334 Bremen, Germany \\ ${ }^{2}$ Alfred Wegener Institute for Polar and Marine Research, Am Handelshafen 12, 27570 Bremerhaven, Germany \\ Correspondence to: D. Fischer (dfischer@marum.de)
}

Received: 1 September 2011 - Published in Biogeosciences Discuss.: 29 September 2011

Revised: 4 May 2012 - Accepted: 15 May 2012 - Published: 7 June 2012

\begin{abstract}
The interaction between fluid seepage, bottom water redox, and chemosynthetic communities was studied at cold seeps across one of the world's largest oxygen minimum zones (OMZ) located at the Makran convergent continental margin. Push cores were obtained from seeps within and below the core-OMZ with a remotely operated vehicle. Extracted sediment pore water was analyzed for sulfide and sulfate concentrations. Depending on oxygen availability in the bottom water, seeps were either colonized by microbial mats or by mats and macrofauna. The latter, including ampharetid polychaetes and vesicomyid clams, occurred in distinct benthic habitats, which were arranged in a concentric fashion around gas orifices. At most sites colonized by microbial mats, hydrogen sulfide was exported into the bottom water. Where macrofauna was widely abundant, hydrogen sulfide was retained within the sediment.

Numerical modeling of pore water profiles was performed in order to assess rates of fluid advection and bioirrigation. While the magnitude of upward fluid flow decreased from $11 \mathrm{~cm} \mathrm{yr}^{-1}$ to $<1 \mathrm{~cm} \mathrm{yr}^{-1}$ and the sulfate/methane transition (SMT) deepened with increasing distance from the central gas orifice, the fluxes of sulfate into the SMT did not significantly differ (6.6-9.3 $\left.\mathrm{mol} \mathrm{m}^{-2} \mathrm{yr}^{-1}\right)$. Depth-integrated rates of bioirrigation increased from $120 \mathrm{~cm} \mathrm{yr}^{-1}$ in the central habitat, characterized by microbial mats and sparse macrofauna, to $297 \mathrm{~cm} \mathrm{yr}^{-1}$ in the habitat of large and few small vesicomyid clams. These results reveal that chemosynthetic macrofauna inhabiting the outer seep habitats below the core-
\end{abstract}

OMZ efficiently bioirrigate and thus transport sulfate down into the upper 10 to $15 \mathrm{~cm}$ of the sediment. In this way the animals deal with the lower upward flux of methane in outer habitats by stimulating rates of anaerobic oxidation of methane (AOM) with sulfate high enough to provide hydrogen sulfide for chemosynthesis. Through bioirrigation, macrofauna engineer their geochemical environment and fuel upward sulfide flux via AOM. Furthermore, due to the introduction of oxygenated bottom water into the sediment via bioirrigation, the depth of the sulfide sink gradually deepens towards outer habitats. We therefore suggest that in addition to the oxygen levels in the water column, which determine whether macrofaunal communities can develop or not - it is the depth of the SMT and thus of sulfide production that determines which chemosynthetic communities are able to exploit the sulfide at depth. We hypothesize that large vesicomyid clams, by efficiently expanding the sulfate zone down into the sediment, could cut off smaller or less mobile organisms, as e.g. small clams and sulfur bacteria, from the sulfide source.

\section{Introduction}

Cold seep sites at the seafloor are created typically by the focused upward migration of both dissolved and/or gaseous hydrocarbons. Seeps are found at passive and active continental margins and generally show strong temporal and spatial 
variations in fluid flux (e.g. Wallmann et al., 1997, 2006; Suess et al., 1998; Tryon et al., 1999; Sahling et al., 2008; Niemann et al., 2009; Reitz et al., 2011). The upward supply of hydrocarbons towards and across the sediment/water interface produces steep geochemical gradients of pore water constituents, and typically stimulates high rates of anaerobic oxidation of methane (AOM) and other hydrocarbons with sulfate as an electron acceptor close to the sediment surface (Borowski et al., 1996; Treude et al., 2003). The process of AOM which is performed by a consortium of archaea and sulfate-reducing bacteria (Hoehler et al., 1994; Hinrichs et al., 1999; Boetius et al., 2000; Knittel and Boetius, 2009) releases hydrogen sulfide and bicarbonate into the pore water at the so-called sulfate/methane transition (SMT). Hence, AOM fuels microbial and macrofaunal chemosynthetic life and generates a significant carbon sink through carbonate authigenesis (e.g. Ritger et al., 1987). Numerous studies have demonstrated that the flux of methane and sulfide towards the sediment/water interface determines the microbial and faunal community composition at cold seeps (e.g. Dando and Hovland, 1992; Barry et al., 1997; Sibuet and Olu, 1998; Sahling et al., 2002; Levin et al., 2003; Treude et al., 2003; van Dover et al., 2003; Arvidson et al., 2004; Levin, 2005; de Beer et al., 2006; Niemann et al., 2006; Niemann et al., 2009; Lichtschlag et al., 2010a).

The convergent continental margin off Pakistan is referred to as the "Makran accretionary prism" and it is named after the Makran coastal desert. Cold seeps off Pakistan and their properties as habitats for chemosynthetic microbial and faunal life were described earlier (Faber et al., 1994; von Rad et al., 1996, 2000; Schmaljohann et al., 2001). Von Rad et al. (2000) found signs for gas seepage mostly on the upper slope $(<1000 \mathrm{~m})$ which they explained to result from local tectonic uplift and hence a destabilization of gas hydrates trapped within the gas hydrate stability zone at greater depth. These authors found that the occurrence of Thioploca sp. and/or Beggiatoa sp. mats in the area is confined to sites punctually expelling free gas or sites of drift-wood or other large pieces of organic matter on the sea floor (von Rad et al., 2000). It has been suggested that local variations in the spatial distribution of benthic, chemosynthetic macrofauna in the study area may be co-induced by the depth of AOMderived sulfide supply and oxygen availability in the bottom water (von Rad et al., 1995, 1996, 2000; Schmaljohann et al., 2001).

The influence of bioirrigation and bioturbation on solute distribution and fluxes in marine sediments has been investigated in detail (e.g. Aller, 1980, 1984; Aller and Aller, 1998; Meile et al., 2001; Cordes et al., 2005; Niemann et al., 2006; Dattagupta et al., 2008). However, only a few studies have quantified the influence of the activity of chemosynthetic biota on benthic fluxes at cold seeps (Wallmann et al., 1997; Haese, 2002; Cordes et al., 2005; Haese et al., 2006). Bioirrigation, described as pumping of pore water by benthic fauna through their environment, is a prominent transport process at cold seeps as these sites are often densely colonized by chemosynthetic macrofauna. Wallmann et al. (1997) proposed that seep biota settling on and within the sulfidic seep sediments can flush their immediate surrounding with bottom water thereby introducing sulfate into the methanic zone of the sediment. On the other hand, macrofauna can only gain access to the sulfide pool needed for chemosymbiosis by digging down into the sediment. Besides sulfide removal by reaction with reactive iron phases (e.g. Berner, 1970), the distribution of sulfide within seep sediments and a potential sulfide export into the water column are controlled by both, the depths and rates of AOM as well as the activity of macrofauna colonizing the sediment surface. Due to the location of the "Makran" cold seeps within and below the core-OMZ and thus due to the distinct distribution of chemosynthetic seep communities on the sediment surface, the study area is ideal for exploring the interaction of water column redox, rates of upward fluid/gas migration, and bioirrigation in cold seep habitats.

In this study we investigated and quantified transport processes in different benthic seep-habitats of the Makran accretionary prism. The particular aim of this work was to elucidate the interaction between the intensity of fluid flux, oxygen levels in the bottom water, colonization with chemosynthetic biota, and solute fluxes towards and across the sediment/water interface. For this purpose we carried out a visual examination (high definition camera) and video-targeted sediment sampling of distinct seep habitats within and below the core-OMZ by means of a remotely operated vehicle (ROV). We quantified pore water flow caused by advection and bioirrigation by means of 1-D-modeling of pore water profiles. We show how seep-dependent macrofauna inhabiting the sediment surface actively shape their geochemical environment and thus control solute fluxes within the sediment and across the sediment/water interface.

\section{Geological setting and local oceanography}

A bathymetric map of the study areas offshore Pakistan is shown in Fig. 1. At the Makran subduction zone, oceanic crust of the Arabian plate and the Omara micro-plate dips northward underneath the Eurasian plate to form the Makran accretionary prism. The deformation front of the Makran prism is located south of the first accretionary ridge at about $3000 \mathrm{~m}$ water depth and strikes West to East, parallel to the coastline of Pakistan (Kukowski et al., 2000, 2001; Ding et al., 2010). Convergence rates range from $36.5-42 \mathrm{~mm} \mathrm{yr}^{-1}$ (Kukowski et al., 2001). A sediment package of 5-7 km thickness accumulated on top of the oceanic crust, which is subject to subduction since at least the Oligocene (Schlüter et al., 2002). Kukowski et al. (2001) pointed out that sediments above the décollement are being accreted by imbricate thrusting, forming well defined coast-parallel accretionary ridges. This N-S cascade of accretionary ridges was mapped in 1997 


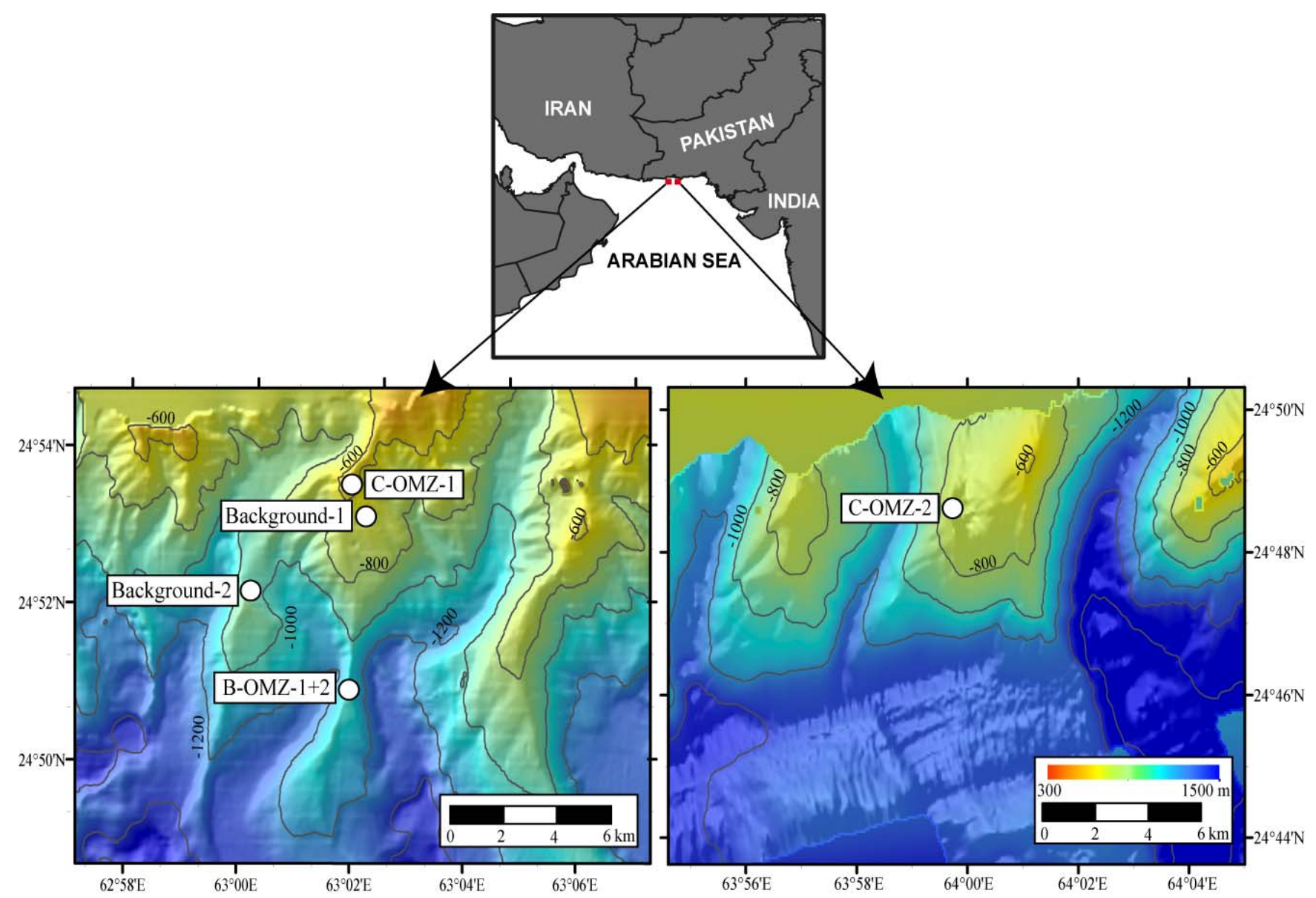

Fig. 1. Overview map of the northern Arabian Sea and detailed bathymetric maps of the examined cold seeps offshore Pakistan. Dots indicate investigated sites. The core of the oxygen minimum zone (oxygen contents $<1 \mu \mathrm{M}$ ) is located at water depths of $400-900 \mathrm{~m}$.

(Kukowski et al., 2000) and a distinct bottom simulating seismic reflector indicative for the phase boundary between free gas below and solid gas hydrates above has been described for the area (Kaul et al., 2000; von Rad et al., 2000; Ding et al., 2010).

The water column off Pakistan is characterized by a pronounced OMZ with oxygen concentrations $<2 \mu \mathrm{M}$ between $100 \mathrm{~m}$ and $1000 \mathrm{~m}$ water depth (Wyrtki, 1973). The OMZ is, however, subject to temporal variations in its vertical extent (Wyrtki, 1973; Olson et al., 1993). The thickness of the OMZ off Pakistan is controlled by the combined effects of moderate to high rates of aerobic degradation of organic matter in the water column and a sluggish supply with warm and saline intermediate waters derived from marginal seas, as for instance the Red Sea and the Persian Gulf (Olson et al., 1993).

\section{Materials and methods}

Sampling took place in the inter-monsoonal period in November 2007 during R/V Meteor cruise M 74/3 (Bohrmann et al., 2008). The main instrument of the cruise was the ROV Marum-Quest 4000. It was deployed at sites of gas discharge into the water column as recorded by echosounder gas flare imaging. Discrete sampling of individual seep habitats as visually identified based on different chemosynthetic microbial and macrobenthic communities was performed by ROV-operated push cores (PCs). Sampling included both the central, as well as the surrounding habitats of single seeps (see Fig. 2). We examined four cold seeps - two within and two below the core-OMZ. The OMZ stations are abbreviated according to bottom water redox and observed filamentous sulfur bacteria (for example C-OMZ-1-o for core-OMZ site 1 colonized by orangecolored bacteria; Table 1). Stations below the OMZ are abbreviated according to bottom water redox and colonization with chemosynthetic communities including filamentous sulfur bacteria or macrofauna (for example B-OMZ-2-sc for below-OMZ site 2 colonized by small clams; Table 1). In addition to the habitat-specific sampling of the four examined seep sites, two sediment cores from background sites ("Background-1", "Background-2") unaffected by hydrocarbon seepage were retrieved with a TV-guided multiple corer 
Table 1. Station list of all examined cores.

\begin{tabular}{|c|c|c|c|c|c|c|c|c|}
\hline $\begin{array}{l}\text { Site-code } \\
\text { (used in text) }\end{array}$ & Flare & GeoB-Station & Gear & Position & Water depth (m) & GHSZ* & $\begin{array}{l}\text { Habitat, Seep } \\
\text { community }\end{array}$ & Water redox \\
\hline C-OMZ-1-o & 1 & $12320-9$ & $\mathrm{PC}$ & $\begin{array}{l}24^{\circ} 53.634 \mathrm{~N} \\
63^{\circ} 01.404 \mathrm{E}\end{array}$ & 551 & - & $\begin{array}{l}\text { orange sulfur } \\
\text { bacteria }\end{array}$ & core-OMZ \\
\hline C-OMZ-1-w & 1 & $12320-4$ & $\mathrm{PC}$ & $\begin{array}{l}24^{\circ} 53.634 \mathrm{~N} \\
63^{\circ} 01.404 \mathrm{E}\end{array}$ & 551 & - & $\begin{array}{l}\text { white sulfur } \\
\text { bacteria }\end{array}$ & core-OMZ \\
\hline Background-1 & & $12312-3$ & MUC & $\begin{array}{l}24^{\circ} 53.072 \mathrm{~N} \\
63^{\circ} 01.641 \mathrm{E}\end{array}$ & 654 & - & Background & core-OMZ \\
\hline C-OMZ-2-o & 15 & $12353-5$ & $\mathrm{PC}$ & $\begin{array}{l}24^{\circ} 48.458 \mathrm{~N} \\
63^{\circ} 59.649 \mathrm{E}\end{array}$ & 732 & - & $\begin{array}{l}\text { orange sulfur } \\
\text { bacteria }\end{array}$ & core-OMZ \\
\hline C-OMZ-2-w & 15 & $12353-3$ & $\mathrm{PC}$ & $\begin{array}{l}24^{\circ} 48.457 \mathrm{~N} \\
63^{\circ} 59.649 \mathrm{E}\end{array}$ & 732 & - & $\begin{array}{l}\text { white sulfur } \\
\text { bacteria }\end{array}$ & core-OMZ \\
\hline Background-2 & & $12309-3$ & MUC & $\begin{array}{l}24^{\circ} 52.322 \mathrm{~N} \\
62^{\circ} 59.859 \mathrm{E}\end{array}$ & 962 & + & Background & core-OMZ \\
\hline B-OMZ-1-w & 2 & $12315-9$ & PC & $\begin{array}{l}24^{\circ} 50.753 \mathrm{~N} \\
63^{\circ} 01.439 \mathrm{E}\end{array}$ & 1025 & + & $\begin{array}{l}\text { white/rose } \\
\text { sulfur bac- } \\
\text { teria, few } \\
\text { polychaetes }\end{array}$ & $\begin{array}{l}\text { below core- } \\
\text { OMZ }\end{array}$ \\
\hline B-OMZ-1-sc & 2 & $12315-4$ & $\mathrm{PC}$ & $\begin{array}{l}24^{\circ} 50.753 \mathrm{~N} \\
63^{\circ} 01.439 \mathrm{E}\end{array}$ & 1025 & + & $\begin{array}{l}\text { polychaetes } \\
\text { and small } \\
\text { clams }\end{array}$ & $\begin{array}{l}\text { below core- } \\
\text { OMZ }\end{array}$ \\
\hline B-OMZ-2-w & 2 & $12313-6$ & $\mathrm{PC}$ & $\begin{array}{l}24^{\circ} 50.828 \mathrm{~N} \\
63^{\circ} 01.419 \mathrm{E}\end{array}$ & 1038 & + & $\begin{array}{l}\text { white/rose } \\
\text { sulfur bac- } \\
\text { teria, few } \\
\text { polychaetes }\end{array}$ & $\begin{array}{l}\text { below core- } \\
\text { OMZ }\end{array}$ \\
\hline B-OMZ-2-sc & 2 & $12313-12$ & $\mathrm{PC}$ & $\begin{array}{l}24^{\circ} 50.828 \mathrm{~N} \\
63^{\circ} 01.419 \mathrm{E}\end{array}$ & 1038 & + & $\begin{array}{l}\text { polychaetes } \\
\text { and small } \\
\text { clams }\end{array}$ & $\begin{array}{l}\text { below core- } \\
\text { OMZ }\end{array}$ \\
\hline B-OMZ-2-lc & 2 & $12313-13$ & $\mathrm{PC}$ & $\begin{array}{l}24^{\circ} 50.829 \mathrm{~N} \\
63^{\circ} 01.419 \mathrm{E}\end{array}$ & 1038 & + & $\begin{array}{l}\text { mainly large } \\
\text { clams }\end{array}$ & $\begin{array}{l}\text { below core- } \\
\text { OMZ }\end{array}$ \\
\hline
\end{tabular}

$*$ GHSZ $=$ Gas hydrate stability zone

(TV-MUC). The exact locations, trivial names and characteristics of all sampling sites are listed in detail in Table 1.

\subsection{Water column characteristics}

Gas flare imaging was conducted with the ship-mounted parametric echosounder system ATLAS PARASOUND as described by Nikolovska et al. (2008). In this study the notation "Flare", as it has been adopted from onboard echosounder identification of potential sampling targets, will be used to specify a major locality. In that, a "Flare" usually comprises a seafloor area of several tens of square meters including sites where more than one actual gas bubble stream was detected in the water column and where hydrocarbon seepage appeared bundled on the sea floor. Water column oxygen concentrations, temperature and salinity were determined during our cruise with a Seabird 911+ CTD equipped with an SBE 43 (Seabird Electronics) oxygen sensor, and temperature and salinity probes. These data were used as input parameters for geochemical modeling and flux calculations.

\subsection{Identification of organisms}

The ROV was equipped with a 3 Mega-pixel photo camera and two video cameras, one of them in HD quality. Images of these three systems were used for visual interpretation of seep habitats (Fig. 2). A tentative differentiation between Beggiatoa spp.-dominated and Marithioploca spp.dominated (formerly known as Thioploca spp.; cf. Salman et al., 2011) filamentous sulfur bacteria was achieved by means of the ROV-cameras. Admitting that this approach is rather weak compared to molecular biological techniques, it may be stated that mats of both genera often appear in different shapes and structures. Marithioploca spp. were reported to appear as lawn-like, white filaments of sufficient length of several $\mathrm{cm}$ to sway in turbulent bottom waters and in a matthickness of several $\mathrm{cm}$ (Fossing et al., 1995; Schulz et al., 1996; Schulz and Jørgensen, 2001; Teske and Nelson, 2006; Salman et al., 2011). Beggiatoa spp. mats, in contrast, were often described to appear as white and/or orange-colored thin skins on the sediment surface with a mat thickness of less than one cm (Nelson et al., 1986; Robinson et al., 2004; Teske and Nelson, 2006; Salman et al., 2011). Macrofauna 


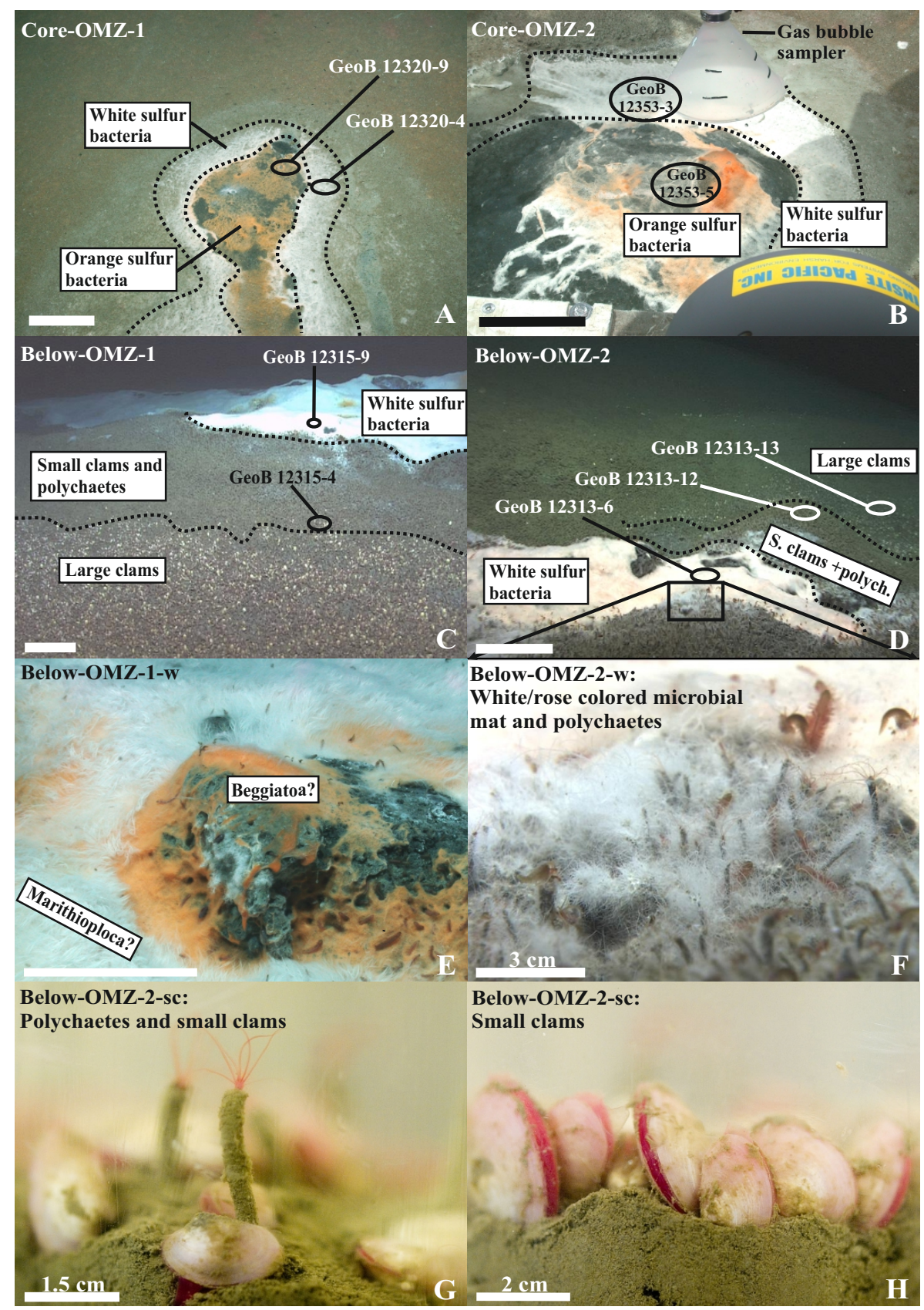

Fig. 2. ROV still images (A-F) and images of retrieved cores (G-H). (A)-(D) Major habitats at all sites are encircled by stippled lines and PC positions are denoted by circles. (E) Close-up of site B-OMZ-1-w, where we found microbial mats of distinctly different appearance (see text). (F) Close-up of the transition from the microbial mat habitat to the small clam and polychaete habitat in (D). (G) Appearance of the small clam and polychaete habitat in a retrieved PC. (H) Appearance of the clam habitat in a retrieved PC. Scale bar is $18 \mathrm{~cm}$ if not denoted otherwise.

(used here as the collective term for clams, polychaetes) specimens were obtained by an ROV-operated net or collected onboard from retrieved PCs and immediately stored in vials filled with $96 \%$ ethanol.

\subsection{Pore water sampling and analyses}

After ROV and TV-MUC retrieval, the sediment cores were immediately transferred into the cold room $\left(4^{\circ} \mathrm{C}\right)$ of the ship and pore water was extracted within one hour by means of rhizons (Seeberg-Elverfeld et al., 2005). The mean pore size of the rhizons is $0.15 \mu \mathrm{m}$ and sampling resolution was 
$1 \mathrm{~cm}$ for the PC and $1-2 \mathrm{~cm}$ for the TV-MUC cores, respectively. Data shown at zero depth in this study represent bottom water concentration. Pore water aliquots for sulfate determination were diluted 1:100 and stored at $-20^{\circ} \mathrm{C}$ until analysis. Sulfate concentrations were measured by ion chromatography (IC) with an Advanced Compact IC 861 (Metrohm). Subsamples for the analysis of total dissolved sulfide $\left(\mathrm{KH}_{2} \mathrm{~S}=\mathrm{H}_{2} \mathrm{~S}+\mathrm{HS}^{-}+\mathrm{S}^{2-}\right)$ were fixed in a $5 \% \mathrm{Zn}$ acetate solution, kept at $4{ }^{\circ} \mathrm{C}$ and measured photometrically according to the methylene-blue method after Cline (1969). The reproducibility of the above methods was verified by analyzing replicate standards. The accuracy of all measurements was within $\pm 3 \%$.

\subsection{Diffusive flux calculations}

Diffusive fluxes of sulfate and sulfide were determined according to Fick's first law of diffusion:

$J_{\text {(species) }}=-\Phi \times D_{\text {sed }} \times \frac{\delta C}{\delta x}$

where $J_{\text {(species) }}$ is the diffusive flux of the dissolved species, $\Phi$ represents sediment porosity, $D_{\text {sed }}$ is the sediment diffusion coefficient in $\mathrm{m}^{2} \mathrm{a}^{-1}$, which was calculated for ambient bottom water temperature as determined by the CTD temperature sensor and corrected for tortuosity (Boudreau, $1997)$, and $\delta C / \delta x$ is the concentration gradient of the dissolved species in $\mathrm{mol} \mathrm{m}^{-4}$. Concentration gradients of sulfide and sulfate were determined from measured pore water profiles obtained for the individual seep habitats.

\subsection{Geochemical modeling with "CoTReM"}

Pore water profiles obtained for PCs taken from the three distinct successive habitats of site Below-OMZ-2 at Flare 2 were modeled with the computer software CoTReM. The aim of this simulation was to assess rates of fluid advection and bioirrigation. The site was chosen for simulation runs because gas hydrates were found within $40-100 \mathrm{~cm}$ sediment depth in several gravity cores within a radius of less than $1 \mathrm{~km}$ around Flare 2 (Bohrmann et al., 2008) and thus the lower boundary concentration of methane in equilibrium with gas hydrates $(85 \mathrm{mM})$ could be estimated following Tishchenko et al. (2005). This approach is consistent, for example, with estimates of in situ methane concentrations used for pore water modeling at gas hydrate-bearing cold seeps on Hydrate Ridge off Oregon, USA (Torres et al., 2002) and at the Hikurangi Margin off New Zealand (Dale et al., 2010).

CoTReM is a one-dimensional (1-D) numerical, nonsteady state transport and reaction model based on an operator splitting approach. The software has been described in great detail elsewhere (e.g. Adler et al., 2000, 2001; Wenzhöfer et al., 2001; Pfeifer et al., 2002). Notably, CoTReM has already been successfully applied to model transport processes and geochemical reactions at two mud volcanoes of the Eastern Mediterranean (Haese et al., 2003, 2006). Considering all relevant transport modes for a solute, CoTReM solves the 1-D steady-state differential Eq. (2) (after Boudreau, 1997):

$D_{\text {sed }} \frac{\delta^{2} C}{\delta x^{2}}+v \frac{\delta C}{\delta x}-\alpha_{x}\left(C_{x}-C_{0}\right)=0$

where the first term describes molecular diffusion, the second term describes advection, and the third term describes bioirrigation, while $C$ is concentration, $x$ is sediment depth, $v$ is advective flow velocity, $\alpha_{x}$ is the nonlocal mixing coefficient and $\left(C_{x}-C_{0}\right)$ is the difference between the concentration at any sediment depth and in the bottom water. A model sediment column of $50 \mathrm{~cm}$ was chosen which was subdivided into cells of $1 \mathrm{~mm}$ thickness. The results are only displayed for the upper $30 \mathrm{~cm}$ of the sediment approximately corresponding to the length of the investigated PCs. Porosity was not determined, because during pore water extraction with rhizons much of the interstitial water had been removed. Porosity was thus assumed to decrease from 0.9 at the sediment surface to 0.8 at a depth of $50 \mathrm{~cm}$ (lower model boundary), which is in accordance with other published pore water models (e.g. Haeckel et al., 2001, 2007). Model testruns with lower porosities $(0.85-0.75)$ did not result in major changes in the shapes of the simulated pore water profiles (average deviation $<5 \%$ ). The time step to fulfill numerical stability was set to $10^{-4}$ yr. Bioirrigation was accounted for by implementing non-local mixing coefficients in the range of published values (e.g. Haese et al., 2006) until best-fit to measured sulfate profiles. Sedimentation rate was ignored due to the simulation of very short time scales. Concentrations of the respective compounds in the supernatant water of the retrieved PCs define the upper boundary conditions. For methane, and at a site covered with white sulfur bacteria (B-OMZ-2-w) also for sulfide, fixed concentrations were defined at the lower model boundary that created the gradients necessary to simulate the respective fluxes into the model area. The only chemical reaction considered in the simulations was AOM with sulfate. A pre-defined maximum AOMrate of $0.5 \mathrm{~mol} \mathrm{dm}^{-3} \mathrm{yr}^{-1}\left(\sim 1.37 \mu \mathrm{mol} \mathrm{cm}{ }^{-3} \mathrm{~d}^{-1}\right)$, which is well in the range of measured values by Treude et al. (2003), was used by the model to create a narrow SMT, as long as the educt species were available in sufficient amounts. As soon as the concentrations decreased, the rates were automatically reduced to match the available amount of reactants in each cell in order to avoid negative concentrations. A compilation of input parameters for the simulation runs is given in Table 2 .

In a second modeling approach we explored how an initially diffusion-dominated sediment/pore water system responds to upward advection and/or bioirrigation at different rates (see Sect. 5.4). The main question behind this simulation was to elucidate to which extent advective pore water flow - either through upward advection, or downward bioirrigation, or a combination of both - affects the depth of the 
Table 2. Input parameters used for pore water modeling of three cores at one site below the core-OMZ.

\begin{tabular}{lc}
\hline Input parameters & Value \\
\hline Length of modeled sediment column & $50 \mathrm{~cm}$ \\
Porosity (upper to lower model boundary) & $0.9-0.8$ \\
Temperature & $12.3^{\circ} \mathrm{C}$ \\
Sulfate concentrations at upper model boundary & $26.3-31.6 \mathrm{mM}$ (see text) \\
Methane concentrations at lower model boundary & $85 \mathrm{mM}$ (see text) \\
Fixed sulfide concentration at lower model boundary (only site B-OMZ-2-w) & $14 \mathrm{mM}$ \\
\hline
\end{tabular}

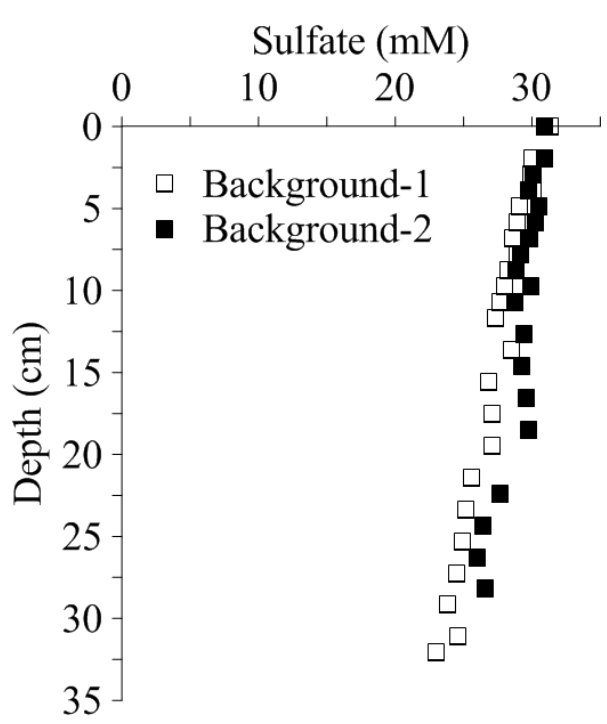

Fig. 3. Pore water sulfate profiles of the two non-seep background TV-MUC cores.

SMT and fluxes of sulfate into the SMT. Boundary conditions chosen for the different scenarios were as described above, however in this approach we implemented the different transport processes consecutively in independent "scenarios".

\section{Results}

\subsection{Background sites}

Sulfate concentration profiles were obtained for two sites that were unaffected by gas release and that were not colonized by chemosynthetic communities (Background-1/-2). The sulfate profiles were linear at both sites and concentrations only slightly decreased with depth from bottom water values of $31 \mathrm{mM}$ to about $26 \mathrm{mM}$ at a depth of $27 \mathrm{~cm}$ at site Background-2 and $23 \mathrm{mM}$ at a depth of $32 \mathrm{~cm}$ at site Background-1 (Fig. 3).

\subsection{Gas seepage}

At all seeps investigated in this study, gas bubble ebullition from distinct gas orifices in the center of the seeps was observed. The gas orifices were always located within mats of orange or white sulfur bacteria and were about $1 \mathrm{~cm}$ in diameter. At the time of sampling, gas flux at the two core-OMZ sites was generally weaker than at those sites below the OMZ (M. Römer, unpublished data). At the latter sites, which were located well within the GHSZ, gas bubbles emanating from the sea floor were observed by means of the ROV-camera to be immediately surrounded by skins of gas hydrate.

\subsection{Seeps within the core-OMZ}

The two shallow-most seeps at water depths of 551 and $732 \mathrm{~m}$ were located within the core-OMZ (oxygen concentrations $<1 \mu \mathrm{M}$; Bohrmann et al., 2008) and above the GHSZ. Seep communities at both sites exclusively consisted of orange-colored filamentous sulfur bacteria in the center $(\mathrm{C}$ OMZ-1-o, C-OMZ-2-o), surrounded by white/rose-colored microbial mats (C-OMZ-1-w, C-OMZ-2-w). The overall diameter of these microbial mats was about 40 and $60 \mathrm{~cm}$, respectively (Fig. 2a and b). Microbial mats at both OMZ seeps were up to $1 \mathrm{~cm}$ thick and appeared chaotic and interwoven (Fig. 2a and b). Microbial mat coverage of the sediment surface was heterogeneous and single filaments could not be resolved with the HD camera. We tentatively identified the orange and white colored filamentous sulfur bacteria at these sites as Beggiatoa spp. or close relatives. Gas bubbles emanated from up to three distinct orifices within the orange mats (C-OMZ-1-o, C-OMZ-2-o). These orange mats were always associated with dark-gray to black surface sediments (Fig. 2a and b) and we could observe blackish sediment grains entrained by gas bubbles ascending from the orifices. Bubble escape from surrounding sites (C-OMZ-1w, C-OMZ-2-w) was not observed. Authigenic carbonates of a very porous and brittle fashion were found in the surface sediments at all core-OMZ sites. They exclusively occurred below the microbial mats.

Pore water data obtained for the orange sulfur bacteria habitats in the core-OMZ (C-OMZ-1-o, C-OMZ-2-o; Fig. 2a and $b)$ show that sulfate concentrations were already well below sea water values close to the sediment surface $(6.77 \mathrm{mM}$ 

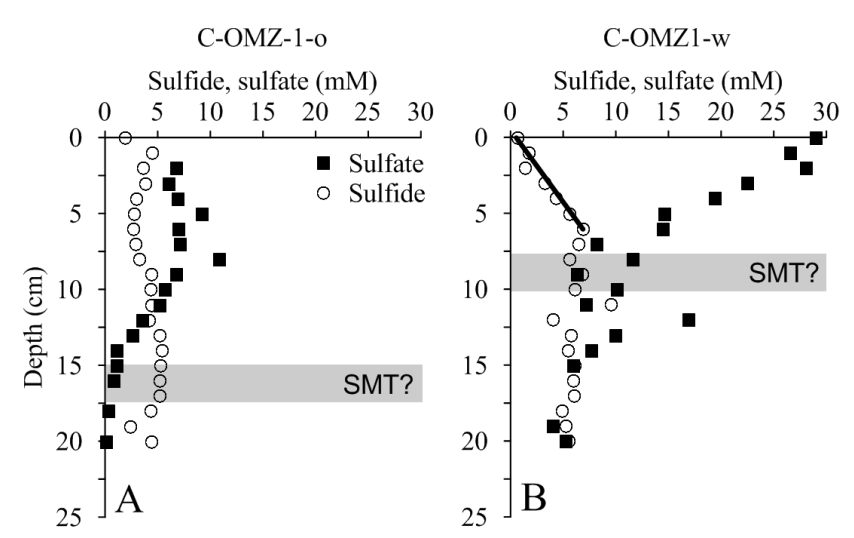

Fig. 4. Pore water profiles of sulfide and sulfate of PCs obtained for seep site 1 within the core-OMZ. Sulfate is not depleted to zero concentration in these cores. Thus, the grey boxes mark the assumed depths of the SMT. Coring positions are marked in Fig. 2 and sampling coordinates are given in Table 1 .
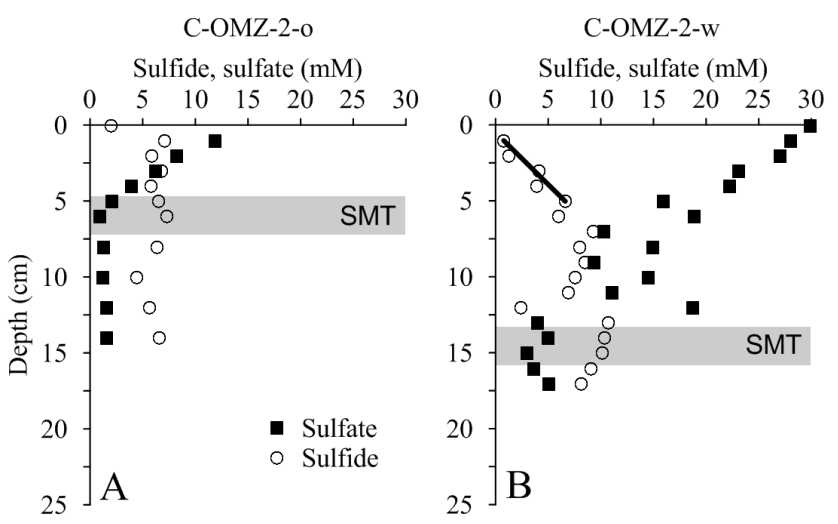

Fig. 5. Pore water profiles of sulfide and sulfate of PCs obtained for seep site 2 within the core-OMZ. See caption of Fig. 4 for further details. Grey boxes mark the assumed depths of the SMT.

and $11.85 \mathrm{mM}$, respectively), and further decreased with depth to minimum concentrations of $0.16 \mathrm{mM}$ and $0.92 \mathrm{mM}$, respectively (Figs. 4a and 5a). Sulfide contents in these habitats were relatively constant over sediment depth and fluctuated between 5 and $6 \mathrm{mM}$, respectively (Figs. 4a and 5a). A concentration gradient of sulfide into the overlying bottom water was observed at both sites, which may be related to ex-situ degassing during core retrieval. Sulfate profiles determined for the surrounding white sulfur bacteria habitats (C-OMZ-1-w, C-OMZ-2-w; Figs. 4b and 5b) show a steep, almost linear downward decrease from seawater values at the sediment surface to lowest concentrations fluctuating around $5 \mathrm{mM}$ at $19 \mathrm{~cm}$ and $15 \mathrm{~cm}$, respectively. Sulfide concentrations at both these sites increased with depth along steep gradients to maximum values of $9.6 \mathrm{mM}$ at $11 \mathrm{~cm}$ (C-OMZ-1w) and $10.7 \mathrm{mM}$ at $13 \mathrm{~cm}$ (C-OMZ-2-w). In these habitats a sulfide concentration gradient into the bottom water was not observed.

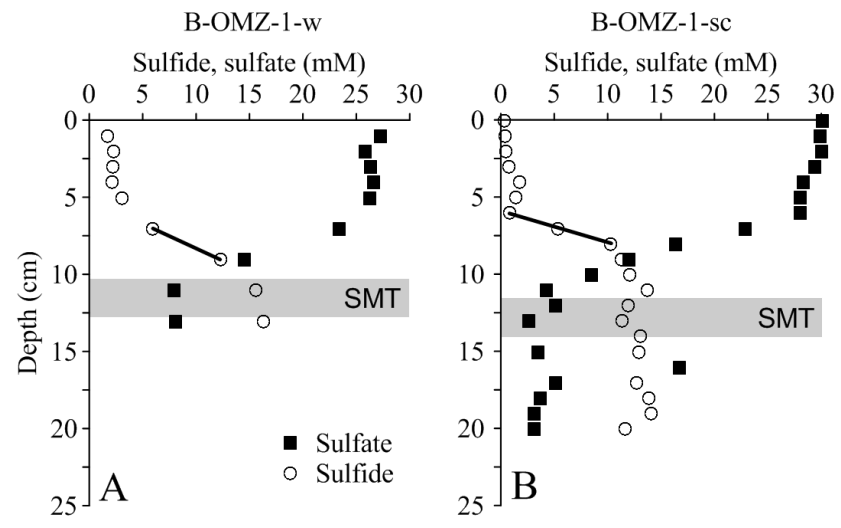

Fig. 6. Pore water profiles of measured (symbols) and modeled (lines) solutes of PCs obtained for seep site 1 below the core-OMZ. See caption of Fig. 4 for further details. Grey boxes mark the assumed depths of the SMT.

\subsection{Seeps at the lower boundary of the OMZ}

The two seeps located below the core-OMZ $(1025 \mathrm{~m}$ and $1038 \mathrm{~m}$ water depth; Fig. 2c and d) were characterized by slightly elevated bottom water oxygen concentrations, compared to core-OMZ sites (Bohrmann et al., 2008), and abundant faunal life both in the water column and at the sea floor. The sediment surface within both central habitats (BOMZ-1-w, B-OMZ-2-w) was draped with $\mathrm{m}^{2}$-sized patches of white/rose-colored filamentous sulfur bacteria surrounding sites of active gas ebullition (Fig. 2c and d). These mats were about $5 \mathrm{~m}$ (B-OMZ-1-w) and $1 \mathrm{~m}$ (B-OMZ-2-w) in diameter, in some places more than $5 \mathrm{~cm}$ thick and appeared as a lawn-like, very soft cover on the sediment surface. The mats at both sites occurred around dm-sized cracks and fissures in the sediment. We could resolve single microbial filaments by means of the HD camera (Fig. 2e and f). However, filament diameter could not be estimated based on these photographs. At one of these sites (B-OMZ-1-w) we found the central white/rose colored sulfur bacteria to be accompanied with and underlain by a several $\mathrm{cm}^{2}$-sized mat of orangecolored microbial filaments that showed a distinctly different appearance including a smaller mat thickness of about $1 \mathrm{~cm}$ (Fig. 2e). Due to the distinctly different filament lengths and pigmentation of both observed mat types we tentatively suggest that they belong to different species. The central orange colored mat at this site resembles Beggiatoa spp.type filaments or close relatives (Fig. 2e), whereas the thick, white mats occurring at both sites below the OMZ resemble Marithioploca spp. or close relatives (Fig. 2e and f).

The central microbial mats at the sites below the OMZ were always surrounded by concentrically arranged habitats of chemosynthetic or grazing/filtering macrofauna. The transition of the mat habitats (B-OMZ-1-w; B-OMZ-2-w) to small clam habitats (B-OMZ-1-sc; B-OMZ-2-sc) was marked by the co-occurrence of bacterial filaments, small 

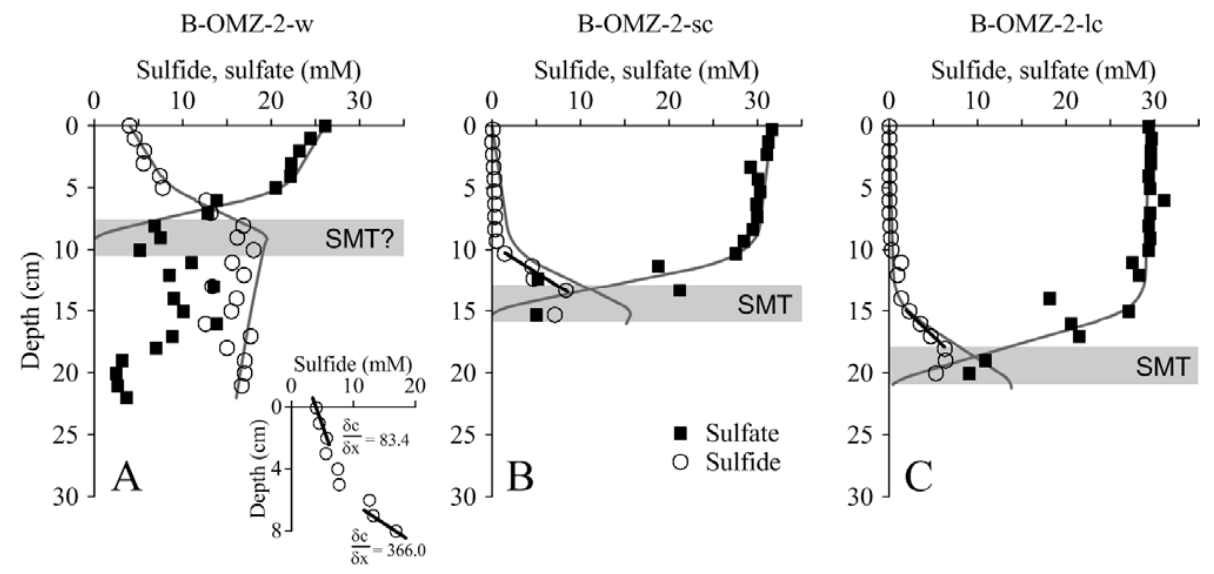

Fig. 7. Pore water profiles of sulfide and sulfate of PCs obtained for seep site 2 below the core-OMZ. See caption of Fig. 4 for further details. Grey boxes mark the assumed depths of the SMT.

vesicomyid clams ( $<3 \mathrm{~cm}$, Isorropodon $\mathrm{sp}$.) and ampharetid polychaetes Pavelius uschakovi (Fig. 2f; Kuznetsov and Levenshtein, 1988). Both the small vesicomyid clams and the ampharetid polychaetes decreased in abundance in outward direction. At one of the seeps below the core-OMZ, we sampled a further habitat that was characterized by few small and abundant large clams (B-OMZ-2-lc, Table 1). In contrast to the core-OMZ seeps, a ubiquitous feature below the OMZ sites was the occurrence of massive authigenic carbonates several $\mathrm{cm}$ in diameter. The carbonates were often, but not exclusively found close to the gas orifices associated with filamentous sulfur bacteria.

Pore water data were obtained for PCs from seeps below the core-OMZ (Figs. 6 and 7). PC sampling of the sulfur bacteria mat habitats was partly complicated by the presence of massive authigenic carbonates. Sulfate concentration profiles obtained for these cores indicated that sulfate contents in the bottom water were depleted compared to bottom water at the background sites depicted in Fig. 3, and only showed a slight decrease down to a depth of about $5 \mathrm{~cm}$ (Figs. 6a and 7a). Below this depth sulfate concentrations sharply decreased to $8 \mathrm{mM}$ (B-OMZ-1-w) at $11 \mathrm{~cm}$ and $5 \mathrm{mM}$ (B-OMZ-2-w) at $10 \mathrm{~cm}$ sediment depth. At the latter site, sulfate concentrations increased again below $10 \mathrm{~cm}$ to reach values of $15 \mathrm{mM}$ between 13 and $17 \mathrm{~cm}$ and then decreased downcore to reach values of about $2 \mathrm{mM}$ at the base of the PC (Fig. 7a). Sulfide concentrations for the two central cores showed a steep downward increase from $1.5 \mathrm{mM}$ at $1 \mathrm{~cm}$ depth to $16.5 \mathrm{mM}$ at $13 \mathrm{~cm}$ depth (B-OMZ-1-w, Fig. 6a) and from $4 \mathrm{mM}$ at the surface to $17.5 \mathrm{mM}$ at a depth of $10 \mathrm{~cm}$ (B-OMZ-2-w, Fig. 7a).

Sulfate profiles obtained for the small clam sites (BOMZ-1-sc; B-OMZ-2-sc; Figs. 6b and 7b) showed background concentrations at the sediment surface and a slight downward decrease within the first 6 and $10 \mathrm{~cm}$, respectively. Below these depths, sulfate concentrations dropped to $3 \mathrm{mM}$ at a depth of $16 \mathrm{~cm}$ (B-OMZ-1-sc) and to $5 \mathrm{mM}$ at a depth of $15 \mathrm{~cm}$ (B-OMZ-2-sc). Sulfide concentrations in both cores fluctuated between $0-2 \mathrm{mM}$ in the upper $5-10 \mathrm{~cm}$ and increased along steep gradients to maximum values of $14 \mathrm{mM}$ (B-OMZ-1-sc) and $8.5 \mathrm{mM}$ (B-OMZ-2-sc) at $11 \mathrm{~cm}$ and $13 \mathrm{~cm}$, respectively (Figs. $6 \mathrm{~b}$ and $7 \mathrm{~b}$ ).

At the large clams site (B-OMZ-2-lc) more or less constant sulfate concentrations were measured from the sediment surface down to a depth of $15 \mathrm{~cm}$, below which sulfide showed a maximum of $6.4 \mathrm{mM}$ at $19 \mathrm{~cm}$ and decreased downwards (Fig. 7c). In general, the depth of the distinct kink in the sulfate pore water profiles at both sites below the core-OMZ deepened with increasing distance to the central gas conduits.

\section{Discussion}

\subsection{Sulfate profiles and the depth of the SMT}

Although displaying different profile shapes, the interstitial sulfate concentrations at all investigated seep habitats strongly decreased in the top $20 \mathrm{~cm}$, indicating that AOM proceeded close to the sediment surface. In contrast, sulfate concentrations at the two background sites (Fig. 3) barely decreased over the sampled sediment interval and represent the non-seep pore water situation in the area, which is governed by diffusion and neither affected by fluid seepage nor shallow hydrocarbon oxidation. The bottom water concentration of sulfate measured in the study area amounts to $31 \mathrm{mM}$ (Fig. 3) and is thus slightly higher than average seawater sulfate values of $\sim 28 \mathrm{mM}$ (Claypool and Kaplan, 1974). Similarly, high bottom-water sulfate concentrations were reported by Schmaljohann et al. (2001) for sediment cores retrieved from similar water depths at the Makran accretionary prism. A reasonable explanation for the elevated bottom water sulfate concentrations in the study area is the inflow of more 
saline intermediate water masses from marginal seas, as e.g. the Red Sea and the Persian Gulf (see Olson et al., 1993).

Sulfate profiles obtained for the core-OMZ sites (Figs. 4 and 5) show distinctly different shapes compared to those obtained for sites below the core-OMZ (Figs. 6 and 7). In the surface sediment layer of orange microbial mat habitats at the core-OMZ sites, we found sulfate concentrations well below measured ambient bottom water values $(\sim 31 \mathrm{mM})$. Following the interpretation by Niemann et al. (2006), low sulfate concentrations at the sediment surface in these central habitats may be caused by high fluid advection, minimizing the diffusion of sulfate into the sediment. Advection usually produces a concave-down curved sulfate profile (Hensen et al., 2003) which was found to a certain extent at one orange bacteria site (C-OMZ-2-o; Fig. 5a). For the white bacteria habitats of the core-OMZ sites we determined linear sulfate profiles that might suggest a diffusion-controlled depth of the SMT, or at least a distinctly lower advection rate than in central orange bacteria habitats (Figs. $4 \mathrm{~b}$ and $5 \mathrm{~b}$ ).

In contrast to the core-OMZ sites, sulfate profiles obtained for all habitats at seeps below the core-OMZ uniformly show distinct "kink-type" or "irrigation-type" profiles (Aller, 1980; Aller and Aller, 1998; Hensen et al., 2003) several $\mathrm{cm}$ below the sediment surface (Figs. 6 and 7). Kink-type sulfate profiles suggest intense irrigation of the sediment surface with sulfate-rich bottom water by the observed polychaetes and clams colonizing these habitats (e.g. Fossing et al., 2000; Haese et al., 2006). Yet, based on the limited bottom water oxygenation at Flare $2(\geq 2 \mu \mathrm{M})$, we suggest that polychaete and clam communities can only be sustained if the OMZ in the water column either shrinks or shifts periodically, and in that way provides enough oxygen for these communities. In fact, it has been stated earlier that the vertical extent of the OMZ off Makran is not stable and undergoes monsoon-forced fluctuations (Wyrtki, 1973; Brand and Griffiths, 2009). It is thus likely that Flare 2 is regularly flushed with oxygen-rich water masses.

It is difficult to identify the actual depths of the SMT at the four investigated seep sites within and below the OMZ, because methane was not determined and sulfate concentrations at all sites except for one (B-OMZ-2-w) did not reach zero. We can therefore only speculate about the approximate depths of the SMT. Nevertheless, the strong depletion in sulfate observed at all sites suggests that the SMT was recovered within the sampled sediment intervals and was located between approximately 5 and $20 \mathrm{~cm}$ (Figs. 4, 5, 6 and 7). Studies from other cold seep environments suggest different processes to cause the presence of sulfate below the assumed SMT, including mixing of bottom water into the sediment due to ex-situ degassing caused by pressure release (Wallace et al., 2000), or ebullition of free gas in situ (Haeckel et al., 2007). The above scenarios are evident for all central microbial mat sites of the present study, where bubble escape was observed. However, we did not observe, e.g. turbid supernatant bottom water in any of the examined cores, which would indicate major mixing due to gas ebullition during core retrieval. Oxidation of sulfide during sample handling and storage has been discussed as an additional source of sulfate in several studies (Luff and Wallmann, 2003; Leloup et al., 2007). Disproportionation of intermediate sulfur species releasing sulfate within the methane zone was identified by Holmkvist et al. (2011) to explain low sulfate contents below the SMT in sediments of the Black Sea. We cannot exclude this process; however, sulfate concentrations below the SMTs reported here are much higher than those shown by Holmkvist and co-workers. Low sulfate concentrations down to $2 \mathrm{mM}$ co-occurring with very high sulfide concentrations of several mM could make bacterial sulfate reduction coupled to AOM thermodynamically unfavorable (Treude et al., 2003; Leloup et al., 2007; Knab et al., 2008; Dale et al., 2010). This may be of significance at two sites (C-OMZ-2w; B-OMZ-2-sc), where we measured concomitant sulfate levels around $2 \mathrm{mM}$ below the SMT and strongly elevated sulfide concentrations of 5 to $10 \mathrm{mM}$. Under these conditions, sulfate reduction coupled to AOM might no longer be feasible and was thus probably strongly retarded or ceased. For sites close to in-situ gas bubble ebullition, a lateral flow of sulfate-rich pore water towards the gas bubble conduit involving convection-like pore water cycling was proposed which would lead to sulfate transport into a discrete layer irrespective of the SMT depth (O'Hara et al., 1995; Tryon et al., 2002; Haeckel and Wallmann, 2008). The study of O'Hara et al. (1995) at gas seeps off Denmark has shown that a draw-down of bottom water into the sediment occurs within a lateral distance of up to $20 \mathrm{~cm}$ from the gas orifice. One site (B-OMZ-2-w) provides strong evidence for this kind of convective flow because the sulfate profile displays a peak between 10 and $20 \mathrm{~cm}$ pointing at a source of sulfate to the pore water in this depth interval (Fig. 7a). The core was obtained within a distance of $<30 \mathrm{~cm}$ from the gas orifice (Fig. 2d) and could thus be affected by convection of bottom water in the sediment (O`Hara et al., 1995). However, cores obtained from small and large clam sites at this site (B-OMZ-2-sc; B-OMZ-2-lc) were obtained at a distance of several $\mathrm{dm}$ to $\mathrm{m}$ from the gas orifice (Fig. 2d) and may thus not be influenced by a draw-down of bottom water into the sediment, which is supported by the absence of pronounced sulfate peaks below the assumed depth of the SMT (Fig. 7b and c). In contrast, the two white mat sites within the OMZ (C-OMZ-1-w and C-OMZ-2-w; Fig. 2a and b) were retrieved within a radius of only $20 \mathrm{~cm}$ around the respective gas orifices and indeed show increases in sulfate concentrations at 12 and $17 \mathrm{~cm}$, respectively (Figs. $4 \mathrm{~b}$ and 5b). Our interpretation of convection-like cycling of pore and bottom water is in accordance with the study by O'Hara et al. (1995) stating that convective cycling of pore and bottom water at gas seeps is an important transport mechanism at sites close to gas orifices and may influence rates of biogeochemical turnover of dissolved species, as e.g. sulfate. 
Table 3. Fluxes of dissolved sulfide and sulfate, as well as depth of steepest sulfide gradient at all seep sites. Fluxes derived from modeled pore water profiles are marked.

\begin{tabular}{lcccc}
\hline Organisms & $\begin{array}{c}\text { White/rose colored mat, } \\
\text { sparse polychaetes } \\
\text { B-OMZ-1-w } \\
\text { B-OMZ-2-w }\end{array}$ & $\begin{array}{c}\text { Polychaetes, } \\
\text { small clams } \\
\text { B-OMZ-1-sc } \\
\text { B-OMZ-2-sc }\end{array}$ & $\begin{array}{c}\text { Small and } \\
\text { large clams } \\
\text { B-OMZ-2-lc }\end{array}$ & $\begin{array}{c}\text { White/rose } \\
\text { colored mat } \\
\text { C-OMZ-1-w } \\
\text { C-OMZ-2-w }\end{array}$ \\
\hline Upward sulfide flux $\left(\mathrm{mol} \mathrm{m}^{-2} \mathrm{yr}^{-1}\right.$ ) & 8.0 & 11.0 & 2.8 & 4.9 \\
Depth of steepest sulfide gradient (cm) & 9.2 & 5.7 & $15-18$ & 3.3 \\
& $3-7$ & $6-8$ & & $1-6$ \\
Sulfate flux into SMT $\left(\mathrm{mol} \mathrm{m}^{-2} \mathrm{yr}^{-1}\right)$ & 9.3 & $10-13$ & 6.6 (modeled) & 7.1 \\
& 9 (modeled) & 8.4 (modeled) & & 4.5 \\
\hline
\end{tabular}

\subsection{Hydrogen sulfide fluxes and chemosynthetic communities}

Upward sulfide fluxes have been widely used in recent publications to describe the geochemical environment of chemosynthetic communities at cold seeps (e.g. Sahling et al., 2002; de Beer et al., 2006; Niemann et al., 2009; Lichtschlag et al., 2010b). Concentration gradients used for hydrogen sulfide flux calculations in this study are indicated as black lines in Figs. 4, 5, 6 and 7. Irrespective of the different organisms colonizing the different habitats at all investigated seeps, we found that hydrogen sulfide fluxes at all sites may potentially support microbial mats (cf. Sahling et al., 2002, Table 3). Sulfide fluxes of $3.3 \mathrm{~mol} \mathrm{~m}^{-2} \mathrm{yr}^{-1}$ and $4.9 \mathrm{~mol} \mathrm{~m}^{-2} \mathrm{yr}^{-1}$ were determined for white filamentous sulfur bacteria sites within the core-OMZ, which were unaffected by in-situ gas bubble ascend at the time of sampling. An export of sulfide into the bottom water is not indicated by pore water profiles at both of these sites (Figs. $4 \mathrm{~b}$ and $5 b)$. The calculated sulfide flux is in the lower range of published values for similar microbial mat habitats for example at the Cascadia margin (Sahling et al., 2002) and at the Håkon Mosby Mud Volcano (de Beer et al., 2006; Lichtschlag et al., 2010a). In fact, Lichtschlag et al. (2010a) found that a sulfide flux of $2.5 \mathrm{~mol} \mathrm{~m}^{-2} \mathrm{yr}^{-1}$ represents the lower threshold for Beggiatoa mats, which is well below the fluxes calculated for the white sulfur bacteria sites within the core-OMZ (C-OMZ1-w; C-OMZ-2-w). In agreement with Gilhooly et al. (2007), we found at the core-OMZ sites that orange Beggiatoa-type microbial mats seem to thrive on high sulfide fluxes towards and across the sediment/water interface, whereas white Beggiatoa-type microbial mats establish at lower sulfide fluxes (Table 3). Sulfide fluxes in these white mat habitats were calculated for shallow sediment depths of $1-6 \mathrm{~cm}$ within the core-OMZ (Table 3), which means that the white bacterial filaments at the sediment surface have access to the subsurface sulfide pool. We calculated higher sulfide fluxes of 2.8$11 \mathrm{~mol} \mathrm{~m}^{-2} \mathrm{yr}^{-1}$ at sites below the core-OMZ colonized by Marithioploca-type microbial mats in the seep center and/or by chemosynthetic macrofauna in outer habitats (Table 3 ).
The sulfide fluxes generally decrease with increasing distance to the central gas orifice, which corresponds well to findings by Sahling et al. (2002). However, in contrast to the core-OMZ sites, the steepest sulfide gradients, and thus the highest fluxes, were found at distinctly greater depths of 3$18 \mathrm{~cm}$ (Table 3). It is known that filaments of Beggiatoa-type bacteria, as well as sheaths of Marithioploca-type bacteria can penetrate into the sediment on scales of $0-8 \mathrm{~cm}$, with the largest abundance of filaments in the uppermost $1-2 \mathrm{~cm}$ (Schulz et al., 1996; Preisler et al., 2007). Although we cannot exclude that there were sulfur bacterial filaments present below the sediment surface of clam sites, we hypothesize that bioirrigation by the observed clams could make it very difficult for filamentous sulfur bacteria to access the sulfide pool. At one microbial mat site below the core-OMZ (B-OMZ-2w) sulfide export across the sediment/water interface is indicated by the sulfide profile (Fig. 7a, inset). The sulfide export into the bottom water amounts to $1.3 \mathrm{~mol} \mathrm{~m}^{-2} \mathrm{yr}^{-1}$ (Table 3, inset in Fig. 7a). We stated earlier that core-retrieval involves a rapid pressure release and may thus lead to ebullition of dissolved gases, including hydrogen sulfide. However, we have observed numerous microbial filaments that were merely attached to carbonate chunks or polychaete tubes exposed above the sediment surface. These filaments were thus cut-off from the interstitial sulfide pool in the sediment (Fig. 2f). We hence assume that the sulfide flux across the sediment/water interface $\left(1.3 \mathrm{~mol} \mathrm{~m}^{-2} \mathrm{yr}^{-1}\right.$, Table 3$)$ at this site is an in situ feature, and that the flux is sufficient to nourish the microbes exposed above the sediment/water interface at the two similar white microbial mat sites (B-OMZ-1-w; B-OMZ-2-w). A similar observation has been reported from cold seeps on the Hikurangi Margin (Sommer et al., 2010), which may indicate that thiotrophic microbes do not necessarily depend on direct access to the pore water sulfide pool, as long as the sulfide export into the bottom water meets their sulfide demand.

Our data show that the magnitude of the upward sulfide flux alone does not determine the colonization of the seeps by chemosynthetic organisms exploiting the sulfide pool, and it does thus not accurately describe their geochemical 
Table 4. Modeled rates of advection and bioirrigation obtained for three cores at one site below the core-OMZ.

\begin{tabular}{lcc}
\hline & $\begin{array}{c}\text { Advection rate } \\
\left(\mathrm{cm} \mathrm{yr}^{-1}\right)\end{array}$ & $\begin{array}{c}\text { Depth-integrated bioirrigation rate } \\
\left(\mathrm{cm} \mathrm{yr}^{-1}\right) ; \text { at a depth of }(\mathrm{cm})\end{array}$ \\
\hline B-OMZ-2-w & 11 & $120 ; 4.1-5.9$ \\
B-OMZ-2-sc & 8 & $210 ; 8.0-11.5$ \\
B-OMZ-2-lc & $<1$ & $297 ; 11.8-15.7$ \\
Similar approach using CoTReM by Haese et al. (2006) & $5-30$ & max. 300; 8-11 \\
\hline
\end{tabular}

environment. It is rather the combination of sulfide flux, the depth of sulfide release (SMT) and the depth of complete sulfide consumption, which determines the colonization of seeps by thiotrophic and/or chemosynthetic communities. We thus address the complex interplay of different transport processes affecting the depth of the SMT in the following sections.

\subsection{Quantifying transport processes - modeling results}

Based on the distinctly different shapes of the pore water profiles at sites below the core-OMZ compared to core-OMZ sites, we addressed the question which transport processes dominate in different seep habitats. The computer model CoTReM has been applied to the three habitats of seep site 2 below the core-OMZ, where we have obtained three PCs from consecutive habitats, in order to quantify the habitatspecific interplay of upward advection and downward bioirrigation. 3-D-modeling of pore water profiles, considering the seep including all habitats as a continuum, would be favorable. However, such an approach would require a much higher sampling density than was achieved during the cruise. For example, the pore water profiles used for modeling derive from three PCs obtained from distinctly different habitats selected by eye. The investigated habitats in total covered an area of more than $25 \mathrm{~m}^{2}$, which is estimated based on observed colonization with chemosynthetic communities. Thus, the pore water profiles of a single PC would represent an area of more than $8 \mathrm{~m}^{2}$ which is not sufficient for 3-D-modeling. We therefore considered each PC to be representative for its respective habitat and applied the 1-D-model in order to estimate the magnitude pore water transport processes. In this respect, it is important to note that modeled transport rates may underestimate the in situ rates, because degassing of the sediment during core retrieval may have led to mixing with bottom water. Simulated profiles of sulfate and sulfide for the modeled PCs are depicted as solid lines in Fig. 7 and advection and bioirrigation rates are given in Table 4.

Upward advective flow velocity was highest $\left(11 \mathrm{~cm} \mathrm{yr}^{-1}\right)$ at the microbial mat site near the gas orifice and decreased with increasing distance to the orifice (B-OMZ-2sc: $8 \mathrm{~cm} \mathrm{yr}^{-1}$ and B-OMZ-2-lc: $\left.<1 \mathrm{~cm} \mathrm{yr}^{-1}\right)$. Published pore water flow velocities of $10 \mathrm{~cm} \mathrm{yr}^{-1}$ (Linke et al., 2005; Costa Rica margin), 1-28 $\mathrm{cm} \mathrm{yr}^{-1}$ (Han and Suess, 1989; Casca- dia margin), and $<200 \mathrm{~cm} \mathrm{yr}^{-1}$ (Tryon et al., 2002; Cascadia margin) determined for other cold seeps compare well to the rates determined here. On the other hand, many studies, most of which deal with mud volcanism, depict much higher rates of material (e.g. fluid, mud) transport of up to several meters per year (e.g. Linke et al., 1994; Wallmann et al., 1997; de Beer et al., 2006; Haese et al., 2006; Kaul et al., 2006; Lichtschlag et al., 2010b). The low advection rates reported here are probably due to the fact that cold seeps, that are not associated with mud volcanism, emit fluids generally slower than mud volcanos.

Depth-integrated rates of bioirrigation increase from $120 \mathrm{~cm} \mathrm{yr}^{-1}$ in the habitat dominated by the microbial mat to $210 \mathrm{~cm} \mathrm{yr}^{-1}$ in the small clam habitat and $297 \mathrm{~cm} \mathrm{yr}^{-1}$ in the large clam habitat (Table 4), including nonlocal mixing coefficients of $80-120 \mathrm{yr}^{-1}$. The rates correspond well with those obtained for a Mediterranean mud volcano by Haese et al. (2006) with a similar approach using CoTReM. Depthintegrated bioirrigation rates of up to $900 \mathrm{~cm} \mathrm{yr}^{-1}$ were obtained by Wallmann et al. (1997) to simulate bioirrigation at active cold seeps in the Aleutian subduction zone. The higher values determined by these authors are probably linked to the fact that pore water advection calculated by Wallmann et al. (1997) is with $340 \mathrm{~cm} \mathrm{yr}^{-1}$ much higher than the maximum velocity determined in this study (Table 4).

The pore water model produces higher maximum concentrations of hydrogen sulfide than those measured in small and large clam habitats (Fig. 7). This is likely due to the fact that the model in our configuration neglects processes of sulfide consumption, as e.g. sulfide uptake by seep organisms (e.g. Arp et al., 1984), precipitation of iron sulfides (e.g. Berner, 1970) or sulfurization of organic matter (e.g. Brüchert, 1998).

\subsection{Schematic evolution of the depth of the SMT and sulfate fluxes - unraveling the relative importance of different transport processes}

Seep fauna are known to modify sediment geochemistry (e.g. Hensen et al., 2003; Cordes et al., 2005; Haese et al., 2006; Dattagupta et al., 2008). Several studies have demonstrated that the interaction of the transport processes bioirrigation and advection significantly influences pore water profiles and solute fluxes at cold seeps (Wallmann et al., 1997; Haese et al., 2006; Niemann et al., 2006). In this section we contribute 


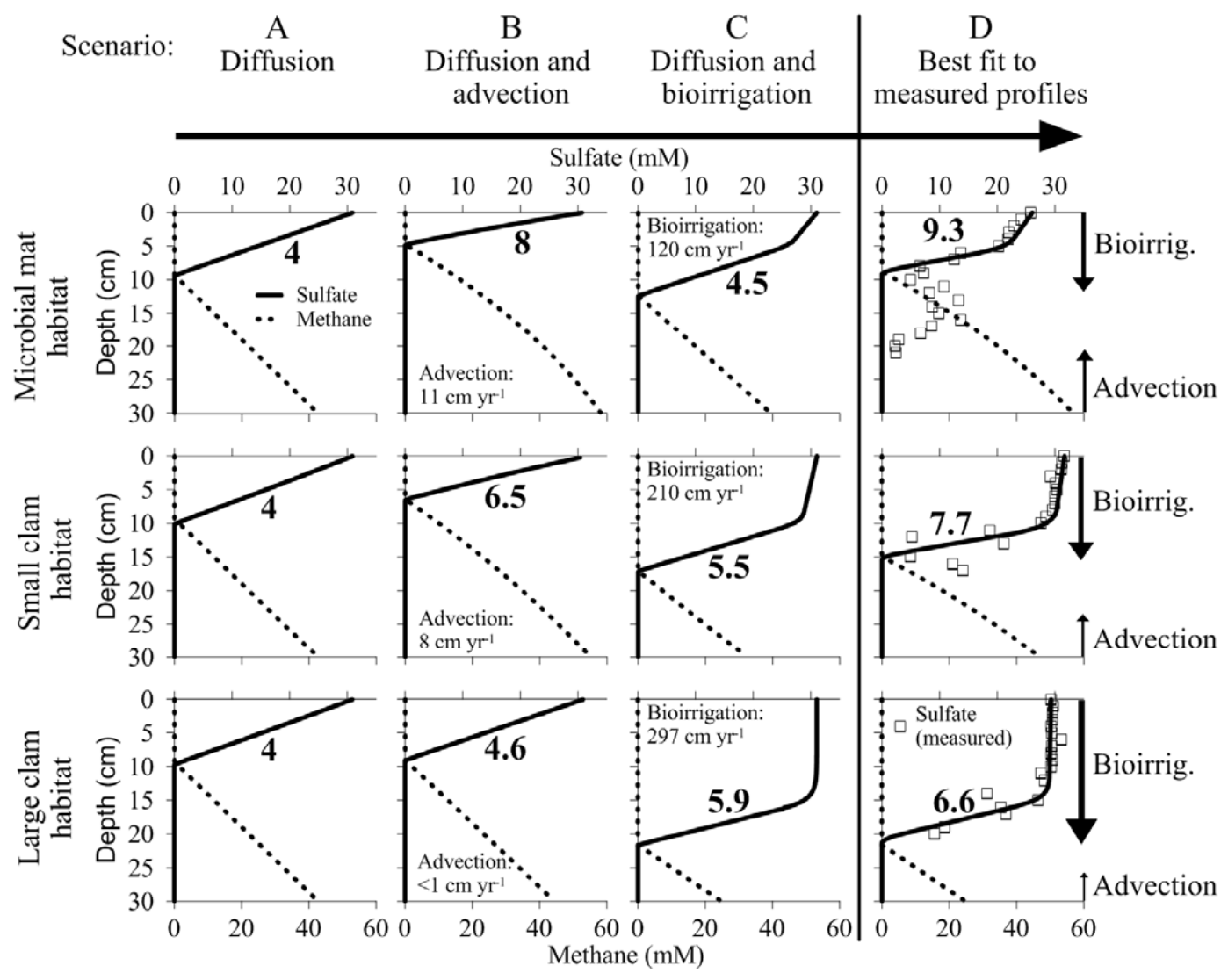

Fig. 8. Stepwise development of modeled sulfate and methane concentration profiles from a diffusively controlled system towards the observed state including advection and bioirrigation. Columns A-D show different "scenarios", whereas rows indicate the three different habitats of seep site 2 below the core-OMZ. Bold numbers next to concentration profiles depict modeled fluxes (mol $\mathrm{m}^{-2} \mathrm{yr}^{-1}$ ) of sulfate into the SMT. Arrows on the right indicate the relative magnitude of the respective transport processes.

further insights into the magnitude and importance of the complex interplay of up- and downward transport processes based on habitat-specific pore water modeling: Fig. 8 depicts a stepwise development of the pore water profiles at the seep site we modeled with CoTReM, from a purely diffusioncontrolled system towards the present (measured) state including upward advection and downward bioirrigation. The initial setting only considers molecular diffusion (Fig. 8, scenario A). It is obvious that the shapes of the sulfate profiles, the sulfate fluxes and the depths of the SMT in Fig. 8, scenario A do not match the measured ones depicted in scenario D. Upward advection was thus simulated for the three examined habitats at different rates in order to approach the observed sulfate gradients (and fluxes) into and the depths of the SMT (Fig. 8, scenario B). We have discussed earlier (Sect. 5.1) that the pore water profiles at the microbial mat site (B-OMZ-2-w) are likely influenced by a convection-like pore water flow, where the central habitat experiences lateral inflow of bottom water balancing the focused fluid escape (O`Hara et al., 1995). Although the model does not consider lateral advection, it was possible to simulate the sulfate concentration gradients and particularly the respective depths of the inferred SMTs in both cores of the small and large clam habitats at this seep site with upward advection. We therefore suggest that an upward advective flow of pore water is present in all three habitats at this seep. The onset of advective pore water flow pushes the SMT towards the sediment surface in all cores and significantly increases sulfate fluxes into the SMT in all habitats (Fig. 8, scenario B). The upward-shifted SMT leads to a shallower sulfide release via $\mathrm{AOM}$ and thus triggers an increased sulfide flux towards the sediment surface in all habitats. In the microbial mat habitat, where the SMT is shallowest (Fig. 8, scenario B), the sulfide flux towards the sediment surface is highest and it decreases towards outer habitats, because the sulfate fluxes into the reaction zone decrease in the same direction. Thus, the advection of pore water in this central habitat triggers a sulfide flux to the sediment surface that meets the high sulfide demand of microbial mats (de Beer et al., 2006), which may settle in the seep-center. In contrast, the lower advection in the small and large clam habitats leads to a weaker upward sulfide flux that meets the demand of chemosynthetic macrofauna, for example clams and polychaetes (Sahling et al., 2005), which may settle in outer habitats. We assume that 
scenario B in Fig. 8 represents the first step in seep colonization which determines whether the sediment surface is colonized by microbial mats in the center (highest sulfide flux) or by chemosynthetic macrofauna (lower sulfide flux in outer habitats). Consequently, simulating the colonization of the seep with chemosynthetic organisms, non-local mixing coefficients (bioirrigation at different rates, Table 4) were implemented into the model to account for initial burrowing activity of animals (Fig. 8, scenario D). Implementation of bioirrigation as a further transport process leads to the distinct gradient changes ("kink-type") that we observed in the measured sulfate profiles, and at the same time shifts the SMT to greater depths due to introduction of sulfate-rich bottom water into the sediment (Fig. 8, scenario D). To test, if the depth of the SMT, sulfate fluxes, and shapes of the sulfate profiles can be sufficiently simulated without upward advection, we started a separate run considering only bioirrigation and diffusion (Fig. 8, scenario C). In this case the general sulfate profile shapes more or less match those of measured profiles, yet the depths of the SMT and sulfate fluxes do not, which highlights the importance of upward advection for initially determining the depth of the SMT in the three examined habitats.

The development of the sulfate fluxes in the different habitats and in the different model scenarios needs further consideration, because the sulfate input into the SMT determines the concentration and flux of released sulfide, which is essential for chemosynthetic communities. In Fig. 8 (scenario D, "present state") the sulfate fluxes into the SMT are given as bold numbers. The fluxes slightly decrease from $9.3 \mathrm{~mol} \mathrm{~m}^{-2} \mathrm{yr}^{-1}$ in the microbial mat habitat to $7.7 \mathrm{~mol} \mathrm{~m}^{-2} \mathrm{yr}^{-1}$ and $6.6 \mathrm{~mol} \mathrm{~m}^{-2} \mathrm{yr}^{-1}$ in the outer habitats. When considering only advection (Fig. 8, scenario B), sulfate fluxes decreased stronger in the same direction, whereas sulfate fluxes stayed similar, when considering only bioirrigation (Fig. 8, scenario C). This comparison shows that the combined transport processes advection and bioirrigation produce a mixed signal in the fluxes of sulfate into the SMT. Thus, the ventilating macrofauna counteract upward advection by shifting the SMT to greater depth and at the same time induce comparably high sulfate fluxes (and high rates of sulfide production) in all three habitats.

Our modeling approach reveals that the counter-directed flow of pore water due to the combined consideration of advection and bioirrigation can explain the measured pore water profiles and the colonization style with different chemosynthetic organisms at this site. Alternative explanations for the successive clam habitats include either different clam species with different sulfide demands (Goffredi and Barry, 2002), or different cohorts of clams. The latter scenario would be reasonable, if for example seepage had decreased in the recent past, which would allow the SMT to establish at greater depth due to the decreased methane flux. If so, central parts of the seep would have been favorable habitats for, e.g. clam larvae to settle, which may explain the occurrence of various generations of clams in the different habitats. However, we have no indications for a decrease in methane flux or seepage intensity. On the contrary, there are indications based on calculated formation ages of authigenic minerals and on pore water transport and reaction modeling that suggest that the methane flux has strongly increased several decades ago at a station at the deformation front located further to the South (data not shown). In fact, the stepwise simulation of diffusion, advection, and bioirrigation (Fig. 8) suggests that it is the combination of upward advection and counteracting downward transport of bottom water by chemosynthetic macrofauna (bioirrigation) that caused a downshift of the SMT, the kink-type sulfate profiles, and ultimately the establishment of at least three different habitats at this seep. It needs to be mentioned, however, that the present state is only a snapshot in time and does not account for future changes in habitat structure. Compared to earlier studies (e.g. Wallmann et al., 1997; Haese et al., 2006) targeted and video-guided sampling of distinct seep-habitats with the ROV enabled us to quantify the complex interplay of bioirrigation and advection and their impact on solute fluxes in the three different habitats of this cold seep.

\subsection{The mutual interaction of geochemistry and chemosynthetic communities}

Comparing the core-OMZ seeps to those located below the core-OMZ, the most prominent feature is that oxygen levels in the bottom water determine, whether a cold seep is colonized exclusively by mat-forming filamentous sulfur bacteria, or by bacteria and surrounding chemosynthetic macrofauna, including ampharetid polychaetes and vesicomyid clams. It has been shown that the initial colonization of seep habitats primarily depends on the shallow production of sulfide (determined by the depth of the SMT), which is controlled by the magnitude of upward methane flux (e.g. Treude et al., 2003). In cases where the sulfidic zone in the sediment can be reached by larvae of e.g. vesicomyid clams, these will settle there and the clams will conduct bioirrigation upon growth. In Sect. 5.4 we suggest that the macrofauna most probably the observed clams - shift the SMT to greater depths and thus increase sulfate fluxes and AOM-rates by bringing the sulfate source closer to the fixed methane source (gas hydrates). This is summarized in the conceptual model given in Fig. 9. The figure shows how animals ventilating bottom water into the sediment surface can establish an extended sulfate zone and thus provide oxic (or at least nonsulfidic) conditions (Fig. 9b). Seeps within the core-OMZ lack colonization by metazoans (Fig. 9a). The fact that clams shift the SMT to greater depth implies that they may gradually proceed towards the seep-center attracted by the shallow and high sulfide flux, and may at the same time undermine and thus cut off smaller organisms (small fauna, sulfur bacteria) from the sulfide source (Figs. 8 and 9). In that way the clams could progressively broaden the sulfate zone and thus 


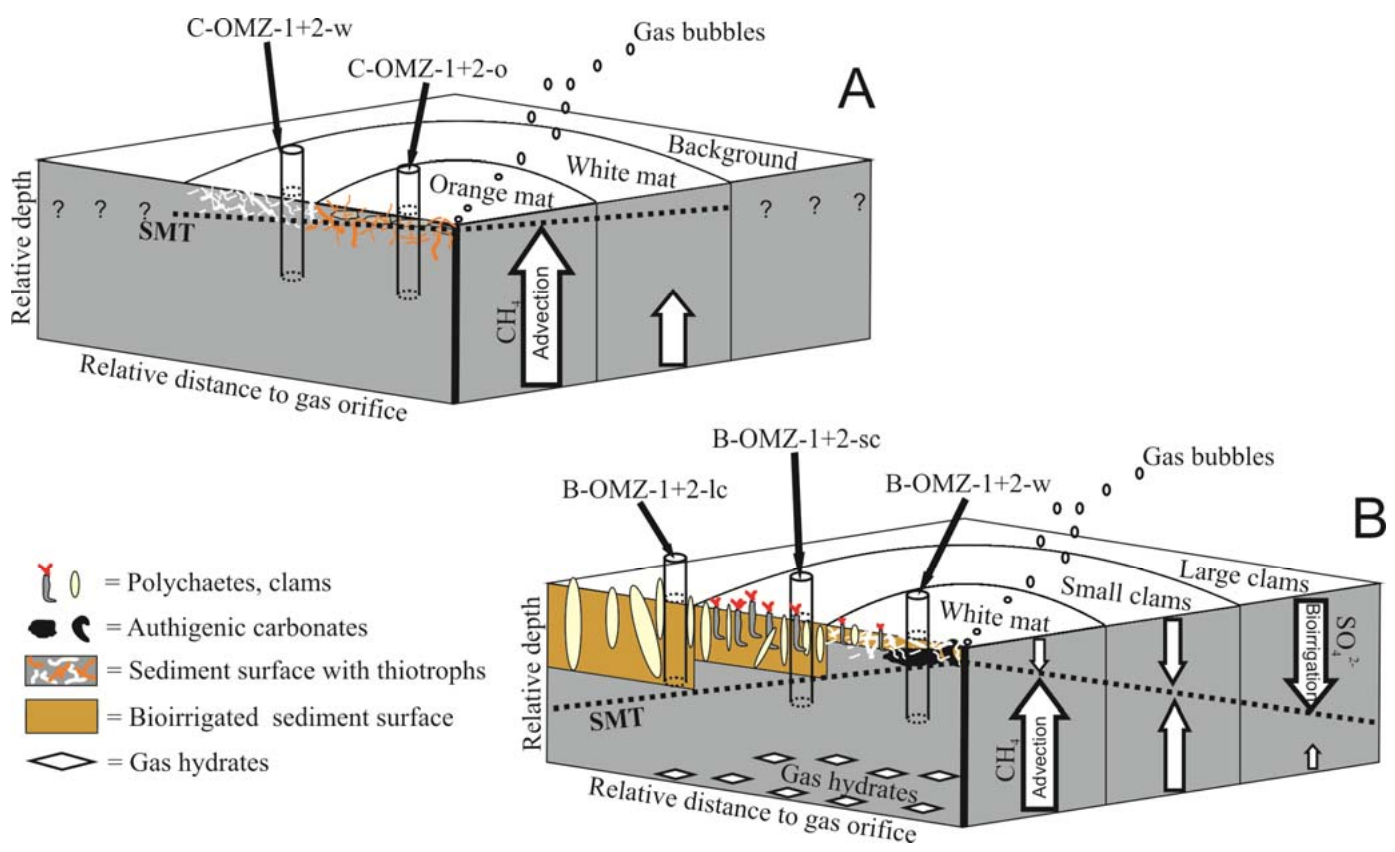

Fig. 9. Schematic illustration of the investigated seeps indicating how chemosynthetic communities impact the depth of the SMT. (A) Situation within the core-OMZ. Oxygen deficiency in the bottom water does not allow for metazoan life and thus sulfur bacteria are the only observed organisms there. The bacteria do not irrigate the sediment surface. Advection is expected at least in the central orange bacteria habitats where bubble escape was observed and where sulfate profiles are curved concave-down. (B) Situation below the core-OMZ. Slightly increased oxygen contents support chemosynthetic communities represented by the observed polychaetes and clams. Compared to the coreOMZ sites, intense bioirrigation leads to a downward shift of the SMT due to high fluxes of sulfate into the sediment, thus compensating upward advection in all habitats.

eventually dominate the respective habitats. It is important to note that the irrigating activity of (large) clams does not only help to detoxify their own habitat from too high sulfide concentrations (Wallmann et al., 1997), but could be an opportunistic means in order to gain advantage over competitive, smaller organisms in accessing the sulfide pool in the sediment.

Sommer et al. $(2008,2010)$ argued that ampharetid polychaete habitats at cold seeps (cf. B-OMZ-1-sc, B-OMZ$\mathrm{s}$-sc in this study) may represent an early stage of seepcolonization by metazoans. Based on our findings we wish to expand upon this idea by suggesting that the occurrence of large clams in the vicinity of gas orifices and without "transient" habitats of medium-sized organisms, such as polychaetes or smaller clams, might indicate a mature stage of a cold seep-ecosystem, where polychaete and small clam communities have been undermined and cut off from the sulfide source in the sediment by opportunistic, dominant large clams. Alternatively, seepage and thus methane flux could have decreased in the recent past, providing not enough sulfide for bacteria to establish at the sediment surface in the seep center, but instead only large clams are present that can reach down to deeper sulfide sources with their foot. However, we do not have indications for a decrease in methane flux in the recent past. Our above statement is further sup- ported by the observation of cold seeps at greater depth $(\sim 1850 \mathrm{~m})$ in the Makran area, which were almost exclusively colonized by large $(<10 \mathrm{~cm})$ vesicomyid clams in the direct vicinity of gas orifices lacking any distinct microbial mat, polychaete or small clam habitats ("Flare 6", cf. Bohrmann et al., 2008). These sites are additionally characterized by massive and $\mathrm{m}^{2}$-scale pavements of authigenic carbonates at the seafloor, which may indicate a longer period of fluid flow and AOM. In contrast to this deeper "Flare 6" (cf. Bohrmann et al., 2008), sites within and below the core-OMZ investigated in this study may represent rather young/juvenile seep ecosystems, which is corroborated by vast "transient" habitats of small chemosynthetic clams and polychaetes and by the sparse occurrence of authigenic carbonates at all investigated sites.

\section{Summary and conclusions}

This is the first study that examines the interplay of bioirrigation and advection in defined cold seep habitats on a transect across a marine oxygen minimum zone (OMZ). We performed targeted push core sampling with a remotely operated vehicle and conducted pore water analyses in different habitats at four seep-sites. Sites within the core-OMZ are characterized by almost linear sulfate profiles and the 
absence of metazoan life. Sites below the core-OMZ depict pronounced kink-type sulfate profiles and are characterized by at least three distinct habitats arranged in a concentric fashion around the gas orifice, which are dominated by filamentous sulfur bacteria, ampharetid polychaetes, or vesicomyid clams of different sizes. Pore water modeling was conducted for one seep below the core-OMZ. The simulation revealed that upward advection is highest near the gas orifice and decreases towards the outer habitats, whereas depthintegrated rates of bioirrigation increase in the same direction due to changes in the colonization of the seep by chemosynthetic communities. Hydrogen sulfide fluxes towards the sediment surface at all sites only slightly decrease towards outer habitats. A sulfide export into the bottom water was found in three of four central habitats colonized by sulfur bacteria, whereas sulfide is depleted at or below the sediment surface in the other habitats. It appears that chemosynthetic macrofauna in outer habitats, here polychaetes and/or clams, counteract the lower supply with sulfide triggered by low advection rates, i.e. methane flux, by introducing sulfate-rich bottom water into the sediment and thus stimulating increased rates of sulfide release via AOM. Furthermore, bioirrigation considerably shifts the sulfate/methane transition (SMT) towards greater depths. At the same time steep gradients and comparably high fluxes of sulfate into the SMT are established in all three habitats, which fuels hydrogen sulfide release via anaerobic oxidation of methane. We hypothesize that chemosynthetic communities dominated by clams and polychaetes actively shape their geochemical environment by shifting the SMT towards depth and gain selective advantage over less mobile organisms (e.g. sulfur bacteria, small clams, polychaetes) competing for hydrogen sulfide in the sediment. Taking into account that macrofauna depend on oxygen supply, we propose that it appears to be the mutual influence of bottom water redox geochemistry and burrowing chemosynthetic organisms that determines the depth of the SMT at cold seeps.

Acknowledgements. We are indebted to the captain, crew and the shipboard scientific party of RV Meteor cruise M 74/3 for excellent support and cooperation. A. Gaßner and K. Enneking (University of Bremen) are thanked for laboratory assistance onboard ship as well as onshore. We would like to thank K. Zonneveld (University of Bremen) for conducting CTD casts and oxygen measurements during the cruise. H. N. Schulz-Vogt (MPI for Marine Microbiology, Bremen) greatly helped with the identification of seep-organisms. M. Haeckel (GEOMAR, Kiel), J. Peckmann (MARUM, Bremen; now University of Vienna), and M. Schlüter (AWI, Bremerhaven) are thanked for numerous valuable discussions. Thanks to D. Fiege (Senckenberg Forschungsinstitut) for polychaete identification. We acknowledge the constructive and insightful comments by two anonymous reviewers and the editor T. Treude (GEOMAR, Kiel). This study was funded through the DFG-Research Center/Cluster of Excellence "The Ocean in the Earth System" (MARUM). We acknowledge further financial support from the Helmholtz
Association (AWI, Bremerhaven). All data are available on the database Pangaea (http://www.pangaea.de).

Edited by: T. Treude

\section{References}

Adler, M., Hensen, C., Kasten, S., and Schulz, H. D.: Computer simulation of deep sulfate reduction in sediments of the Amazon Fan, Int. J. Earth Sci., 88, 641-654, 2000.

Adler, M., Hensen, C., Wenzhöfer, F., Pfeifer, K., and Schulz, H. D.: Modeling of calcite dissolution by oxic respiration in supralysoclinal deep-sea sediments, Mar. Geol., 177, 167-189, 2001.

Aller, R. C.: Quantifying solute distributions in the bioturbated zone of marine sediments by defining an average microenvironment, Geochim. Cosmochim. Acta, 44, 1955-1965, 1980.

Aller, R. C.: The importance of relict burrow structures and burrow irrigation in controlling sedimentary solute distributions, Geochim. Cosmochim. Acta, 48, 1929-1934, 1984.

Aller, R. C. and Aller, J. Y.: The effect of biogenic irrigation intensity and solute exchange on diagenetic reaction rates in marine sediments, J. Mar. Res., 56, 905-936, 1998.

Arp, A. J., Childress, J. J., and Fisher Jr., C. R.: Metabolic and blood gas transport characteristics of the hydrothermal vent bivalve calyptogena magnifica, Physiol. Zool., 57, 648-662, 1984.

Arvidson, R. S., Morse, J. W., and Joye, S. B.: The sulfur biogeochemistry of chemosynthetic cold seep communities, Gulf of Mexico, USA, Mar. Chem., 87, 97-119, 2004.

Barry, J. P., Kochevar, R. E., and Baxter, C. H.: The influence of pore-water chemistry and physiology on the distribution of vesicomyid clams at cold seeps in Monterey Bay: Implications for patterns of chemosynthetic community organization, Limnol. Oceanogr., 42, 318-328, 1997.

Berner, R. A.: Sedimentary pyrite formation, Am. J. Sci., 268, 1-23, 1970.

Boetius, A., Ravenschlag, K., Schubert, C. J., Rickert, D., Widdel, F., Gieseke, A., Amann, R., Jørgensen, B. B., Witte, U., and Pfannkuche, O.: A marine microbial consortium apparently mediating anaerobic oxidation of methane, Nature, 407, 623-626, 2000.

Bohrmann, G., Bahr, A., Brinkmann, F., Brüning, M., Buhmann, S., Diekamp, V., Enneking, K., Fischer, D., Gassner, A., von Halem, G., Huettich, D., Kasten, S., Klapp, S., Nasir, M., Nowald, N., Ochsenhirt, W.-T., Pape, T., Ratmeyer, V., Rehage, R., Rethemeyer, J., Reuter, M., Rossel, P., Saleem, M., Schmidt, W., Seiter, C., Stephan, S., Thomanek, K., Wittenberg, N., Yoshinaga, M. and Zonneveld, K.: Report and preliminary results of R/V Meteor cruise M74/3, Fujairah-Male, 30 October-28 November, 2007. Cold seeps of the Makran subduction zone (Continental margin off Pakistan), Berichte, Fachbereich 5, Universität Bremen, edited by: Bohrmann, G. and Ohling, G., Bremen, 161 pp., 2008.

Borowski, W. S., Paull, C. K., and Ussler III, W.: Marine pore-water sulfate profiles indicate in situ methane flux from underlying gas hydrate, Geology, 24, 655-658, 1996.

Boudreau, B. P.: Diagenetic models and their implementations., Springer-Verlag, New York, 1997.

Brand, T. D. and Griffiths, C.: Seasonality in the hydrography and biogeochemistry across the Pakistan margin of the NE Arabian Sea, Deep Sea Res. Part II, 56, 283-295, 2009. 
Brüchert, V.: Early diagenesis of sulfur in estuarine sediments: the role of sedimentary humic and fulvic acids, Geochim. Cosmochim. Acta, 62, 1567-1586, 1998.

Claypool, G. E. and Kaplan, I. R.: The origin and distribution of methane in marine sediments, in: Natural gases in marine sediments, edited by: Kaplan, I. R., Plenum Publishing Corporation, New York, 1974.

Cline, J. D.: Spectrophotometric determination of hydrogen sulfide in natural waters, Limnol. Oceanogr., 14, 454-458, 1969.

Cordes, E. E., Hourdez, S., Predmore, B. L., Redding, M. L., and Fisher, C. R.: Succession of hydrocarbon seep communities associated with the long-lived foundation species lamellibrachia luymesi, Mar. Ecol. Prog. Ser., 305, 17-29, 2005.

Dale, A. W., Sommer, S., Haeckel, M., Wallmann, K., Linke, P., Wegener, G., and Pfannkuche, O.: Pathways and regulation of carbon, sulfur and energy transfer in marine sediments overlying methane gas hydrates on the Opouawe Bank (New Zealand), Geochim. Cosmochim. Acta, 74, 5763-5784, 2010.

Dando, P. R. and Hovland, M.: Environmental effects of submarine seeping natural gas, Cont. Shelf Res., 12, 1197-1207, 1992.

Dattagupta, S., Arthur, M. A., and Fisher, C. R.: Modification of sediment geochemistry by the hydrocarbon seep tubeworm lamellibrachia luymesi: A combined empirical and modeling approach, Geochim. Cosmochim. Acta, 72, 2298-2315, 2008.

de Beer, D., Sauter, E., Niemann, H., Kaul, N., Foucher, J.-P., Witte, U., Schlüter, M., and Boetius, A.: In situ fluxes and zonation of microbial activity in surface sediments of the Håkon Mosby Mud Volcano, Limnol. Oceanogr., 51, 1315-1331, 2006.

Ding, F., Spiess, V., Fekete, N., Murton, B., Brüning, M., and Bohrmann, G.: Interaction between accretionary thrust faulting and slope sedimentation at the frontal Makran accretionary prism and its implications for hydrocarbon fluid seepage, J. Geophys. Res., 115, B08106, doi:10.1029/2008JB006246, 2010.

Faber, E., Gerling, P., Berner, U., and Sohns, E.: Methane in ocean waters: Concentrations and carbon isotope variability at East Pacific Rise and the Arabian Sea, Environ. Monit. Assess., 31, 139144, 1994.

Fossing, H., Gallardo, V. A., Jørgensen, B. B., Hüttel, M., Nielsen, L. P., Schulz, H., Canfield, D. E., Forster, S., Glud, R. N., Gundersen, J. K., Küver, J., Ramsing, N. B., Teske, A., Thamdrup, B., and Ulloa, O.: Concentration and transport of nitrate by the mat-forming sulphur bacterium Thioploca, Nature, 374, 713715,1995 .

Fossing, H., Ferdelman, T. G., and Berg, P.: Sulfate reduction and methane oxidation in continental margin sediments influenced by irrigation (South-East Atlantic off Namibia), Geochim. Cosmochim. Acta, 64, 897-910, 2000.

Gilhooly III, W. P., Carney, R. S., and Macko, S. A.: Relationships between sulfide-oxidizing bacterial mats and their carbon sources in northern Gulf of Mexico cold seeps, Org. Geochem., 38, 380-393, 2007.

Goffredi, S. K. and Barry, J. P.: Species-specific variation in sulfide physiology between closely related Vesicomyid clams, MEPS 225, 227-238, 2002

Haeckel, M. and Wallmann, K.: Indications for convective flow induced by focussed fluid venting at bacterial mats, Geochim. Cosmochim. Acta, 72, A339-A405, 2008.

Haeckel, M., König, I., Riech, V., Weber, M. E., and Suess, E.: Pore water profiles and numerical modelling of biogeochemical pro- cesses in peru basin deep-sea sediments, Deep Sea Res. Part II, 48, 3713-3736, 2001.

Haeckel, M., Boudreau, B. P., and Wallmann, K.: Bubble-induced porewater mixing: A 3-D model for deep porewater irrigation., Geochim. Cosmochim. Acta, 71, 5135-5154, 2007.

Haese, R. R.: Macrobenthic activity and its effects on biogeochemical reactions and fluxes, in: Ocean Margin Systems, edited by: Wefer, G., Billet, D., Hebbeln, D., Jørgensen, B. B., Schlüter, M., and Van Weering, T., Springer Verlag, Berlin, Heidelberg, 219234, 2002.

Haese, R. R., Meile, C., Van Cappellen, P., and De Lange, G. J.: Carbon geochemistry of cold seeps: Methane fluxes and transformation in sediments from Kazan mud volcano, eastern Mediterranean Sea, Earth Planet. Sci. Lett., 212, 361-375, 2003.

Haese, R. R., Hensen, C., and de Lange, G. J.: Pore water geochemistry of eastern Mediterranean mud volcanoes: Implications for fluid transport and fluid origin, Mar. Geol., 225, 191-208, 2006.

Han, M. W. and Suess, E.: Subduction-induced pore fluid venting and the formation of authigenic carbonates along the cascadia continental margin: Implications for the global Ca-cycle, Palaeogeography, Palaeoclimatology, Palaeoecology, 71, 97-118, 1989.

Hensen, C., Zabel, M., Pfeifer, K., Schwenk, T., Kasten, S., Riedinger, N., Schulz, H. D., and Boetius, A.: Control of sulfate pore-water profiles by sedimentary events and the significance of anaerobic oxidation of methane for the burial of sulfur in marine sediments, Geochim. Cosmochim. Acta, 67, 2631-2647, 2003.

Hinrichs, K.-U., Hayes, J. M., Sylva, S. P., Brewer, P. G., and DeLong, E. F.: Methane-consuming archaebacteria in marine sediments, Nature, 398, 802-805, 1999.

Hoehler, T., Alperin, M. J., Albert, D. B., and Martens, C.: Field and laboratory studies of methane oxidation in an anoxic marine sediment: evidence for a methanogen-sulfate reducer consortium, Global Biogeochem. Cycles, 8, 451-463, 1994.

Holmkvist, L., Ferdelman, T. G., and Jørgensen, B. B.: A cryptic sulfur cycle driven by iron in the methane zone of marine sediment (Aarhus Bay, Denmark), Geochim. Cosmochim. Acta, 75, 3581-3599, 2011.

Kaul, N., Rosenberger, A., and Villinger, H.: Comparison of measured and BSR-derived heat flow values, Makran accretionary prism, Pakistan, Mar. Geol., 164, 37-51, 2000.

Kaul, N., Foucher, J. P., and Heesemann, M.: Estimating mud expulsion rates from temperature measurements on Håkon Mosby Mud Volcano, SW Barents Sea. Mar. Geol. 229, 1-14, 2006.

Knab, N. J., Dale, A. W., Lettmann, K., Fossing, H., and Jørgensen, B. B.: Thermodynamic and kinetic control on anaerobic oxidation of methane in marine sediments, Geochim. Cosmochim. Acta, 72, 3746-3757, 2008.

Knittel, K. and Boetius, A.: Anaerobic oxidation of methane: Progress with an unknown process, Annu. Rev. Microbiol., 63, 311-334, doi:10.1146/annurev.micro.61.080706.093130, 2009.

Kukowski, N., Schillhorn, T., Flueh, E. R., and Huhn, K.: Newly identified strike-slip plate boundary in the northeastern Arabian Sea, Geology, 28, 355-358, 2000.

Kukowski, N., Schillhorn, T., Huhn, K., von Rad, U., Husen, S., and Flueh, E. R.: Morphotectonics and mechanics of the central Makran accretionary wedge off Pakistan, Mar. Geol., 173, 1-19, 2001.

Kuznetsov, A. P. and Levenshtein, R. Y.: Pavelius uschakovi gen. et sp. n. (Polychaeta, Ampharetidae) from the area of the Para- 
mushir gas hydrate vent in the Sea of Okhotsk., Zoologicheskiy zhurnal, 6, 819-825, 1988 (in Russian).

Leloup, J., Loy, A., Knab, N. J., Borowski, C., Wagner, M., and Jørgensen, B. B.: Diversity and abundance of sulfate-reducing microorganisms in the sulfate and methane zones of a marine sediment, Black Sea, Environ. Microbiol., 9, 131-142, 2007.

Levin, L. A.: Ecology of cold seep sediments: interactions of fauna with flow, chemistry and microbes, Oceanogr. Mar. Biol. Annu. Rev., 43, 1-46, 2005.

Levin, L., Ziebis, W., Mendoza, G. F., Growney, V. A., Tryon, M., Brown, K. M., Mahn, C., Gieskes, J. M., and Rathburn, A. E.: Spatial heterogeneity of macrofauna at northern California methane seeps: influence of sulfide concentration and fluid flow, Mar. Ecol. Prog. Ser., 265, 123-139, 2003.

Lichtschlag, A., Felden, J., Brüchert, V., Boetius, A., and de Beer, D.: Geochemical processes and chemosynthetic primary production in different thiotrophic mats of the Håkon Mosby Mud Volcano (Barents Sea), Limnol. Oceanogr., 55, 931-949, 2010a.

Lichtschlag, A., Felden, J., Wenzhöfer, F., Schubotz, F., Ertefai, T. F., Boetius, A., and de Beer, D.: Methane and sulfide fluxes in permanent anoxia: In situ studies at the Dvurechenskii mud volcano (Sorokin Trough, Black Sea), Geochim. Cosmochim. Acta, 74, 5002-5018, 2010b.

Linke, P., Suess, E., Torres, M., Martens, V., Rugh, W. D., Ziebis, W., and Kulm, L. D.: In situ measurement of fluid flow from cold seeps at active continental margins, Deep Sea Res. Part I, 41, 721-739, 1994.

Linke, P., Wallmann, K., Suess, E., Hensen, C., and Rehder, G.: In situ benthic fluxes from an intermittently active mud volcano at the Costa Rica convergent margin, Earth Planet. Sci. Lett., 235, 79-95, 2005.

Luff, R. and Wallmann, K.: Fluid flow, methane fluxes, carbonate precipitation and biogeochemical turnover in gas hydrate-bearing sediments at Hydrate Ridge, Cascadia Margin: numerical modeling and mass balances, Geochim. Cosmochim. Acta, 67, 34033421, 2003.

Meile, C., Koretsky, C., and van Cappellen, P.: Quantifying bioirrigation in aquatic sediments: an inverse modeling approach, Limnol. Oceanogr., 46, 164-177, 2001.

Nelson, D. C., Jorgensen, B. B., and Revsbech, N. P.: Growth pattern and yield of a chemoautotrophic Beggiatoa sp. in oxygensulfide microgradients, Appl. Environ. Microbiol., 52, 225-233, 1986.

Niemann, H., Lösekann, T., de Beer, D., Elvert, M., Nadalig, T., Knittel, K., Amann, R., Sauter, E. J., Schlüter, M., Klages, M., Foucher, J. P., and Boetius, A.: Novel microbial communities of the Haakon Mosby mud volcano and their role as a methane sink, Nature, 443, 854-858, 2006.

Niemann, H., Fischer, D., Graffe, D., Knittel, K., Montiel, A., Heilmayer, O., Nöthen, K., Pape, T., Kasten, S., Bohrmann, G., Boetius, A., and Gutt, J.: Biogeochemistry of a low-activity cold seep in the Larsen B area, western Weddell Sea, Antarctica, Biogeosciences, 6, 2383-2395, doi:10.5194/bg-6-2383-2009, 2009.

Nikolovska, A., Sahling, H., and Bohrmann, G.: Hydroacoustic methodology for detection, localization, and quantification of gas bubbles rising from the seafloor at gas seeps from the eastern Black Sea, Geochem. Geophys. Geosyst., 9, Q10010, doi:10.1029/2008GC002118, 2008.
O’Hara, S. C. M., Dando, P. R., Schuster, U., Bennis, A., Boyle, J. D., Chui, F. T. W., Hatherell, T. V. J., Niven, S. J., and Taylor, L. J.: Gas seep induced interstitial water circulation: observations and environmental implications, Cont. Shelf Res., 15, 931-948, 1995.

Olson, D. B., Hitchcock, G. L., Fine, R. A., and Warren, B. A.: Maintenance of the low-oxygen layer in the central Arabian Sea, Deep-Sea Research Part II - Topical Studies in Oceanography, 40, 673-685, 1993.

Pfeifer, K., Hensen, C., Adler, M., Wenzhöfer, F., Weber, B., and Schulz, H. D.: Modeling of subsurface calcite dissolution, including the respiration and reoxidation processes of marine sediments in the region of equatorial upwelling off Gabon, Geochim. Cosmochim. Acta, 66, 4247-4259, 2002.

Preisler, A., de Beer, D., Lichtschlag, A., Lavik, G., Boetius, A., and Jørgensen, B. B.: Biological and chemical sulfide oxidation in a Beggiatoa inhabited marine sediment, The ISME Journal, 1, 341-353, 2007.

Reitz, A., Pape, T., Haeckel, M., Schmidt, M., Berner, U., Scholz, F., Liebetrau, V., Aloisi, G., Weise, S. M., and Wallmann, K.: Sources of fluids and gases expelled at cold seeps offshore Georgia, eastern Black Sea, Geochim. Cosmochim. Acta, 75, 32503268, 2011.

Ritger, S., Carson, B., and Suess, E.: Methane-derived authigenic carbonates formed by subduction-induced pore-water expulsion along the Oregon/Washington margin, Geol. Soc. Am. Bull., 98, 147-156, 1987.

Robinson, C. A., Bernhard, J. M., Levin, L. A., Mendoza, G. F., and Blanks, J. K.: Surficial hydrocarbon seep infauna from the Blake Ridge (Atlantic Ocean, $2150 \mathrm{~m}$ ) and the Gulf of Mexico (690-2240 m), Mar. Ecol., 25, 313-336, 2004.

Sahling, H., Rickert, D., Lee, R. W., Linke, P., and Suess, E.: Macrofaunal community structure and sulfide flux at gas hydrate deposits from the Cascadia convergent margin, NE Pacific, Mar. Ecol. Prog. Ser., 231, 121-138, 2002.

Sahling, H., Wallmann, K., Dählmann, A., Schmaljohann, R., and Petersen, S.: The physicochemical habitat of Sclerolinum sp. at Hook Ridge hydrothermal vent, Bransfield Strait, Antarctica, Limnol. Oceanogr., 50, 598-606, 2005.

Sahling, H., Bohrmann, G., Spiess, V., Bialas, J., Breitzke, M., Ivanov, M., Kasten, S., Krastel, S., and Schneider, R.: Pockmarks in the Northern Congo Fan area, SW Africa: Complex seafloor features shaped by fluid flow, Mar. Geol., 249, 206-225, 2008.

Salman, V., Amann, R., Girnth, A.-C., Polerecky, L., Bailey, J. V., Høgslund, S., Jessen, G., Pantoja, S., and Schulz-Vogt, H. N.: A single-cell sequencing approach to the classification of large, vacuolated sulfur bacteria, Syst. Appl. Microbiol., 34, 243-259, 2011.

Schlüter, H. U., Prexl, A., Gaedicke, C., Roeser, H., Reichert, C., Meyer, H., and von Daniels, C.: The Makran accretionary wedge: sediment thicknesses and ages and the origin of mud volcanoes, Mar. Geol., 185, 219-232, 2002.

Schmaljohann, R., Drews, M., Walter, S., Linke, P., Rad, U. v., and Imhoff, J. F.: Oxygen-minimum zone sediments in the northeastern Arabian Sea off Pakistan: a habitat for the bacterium Thioploca, Mar. Ecol. Prog. Ser., 211, 27-42, 2001.

Schulz, H. N. and Jørgensen, B. B.: Big Bacteria, Annu. Rev. Microbiol., 55, 105-137, 2001. 
Schulz, H. N., Jørgensen, B. B., Fossing, H. A., and Ramsing, N. B.: Community Structure of Filamentous, Sheath-Building Sulfur Bacteria, Thioploca spp., off the Coast of Chile, Appl. Environ. Microbiol., 62, 1855-1862, 1996.

Seeberg-Elverfeld, J., Schlüter, M., Feseker, T., and Kölling, M.: Rhizon sampling of porewaters near the sediment-water interface of aquatic systems, Limnol. Oceanogr. Methods, 3, 361371,2005 .

Sibuet, M. and Olu, K.: Biogeography, biodiversity and fluid dependence of deep-sea cold-seep communities at active and passive margins, Deep Sea Res. Part II, 45, 517-567, 1998.

Sommer, S., Linke, P., Pfannkuche, O., Bowden, D. A., Haeckel, M., Greinert, J., and Thurber, A. R.: Novel cold seep habitat along the Hikurangi Margin (New Zealand), Geophys. Res. Abstr., 10, EGU2008-A-02387, 2008.

Sommer, S., Linke, P., Pfannkuche, O., Niemann, H., and Treude, T.: Benthic respiration in a seep habitat dominated by dense beds of ampharetid polychaetes at the Hikurangi Margin (New Zealand), Mar. Geol., 272, 223-232, 2010.

Suess, E., Bohrmann, G., von Huene, R., Linke, P., Wallmann, K., Lammers, S., Sahling, H., Winckler, G., Lutz, R. A., and Orange, D.: Fluid venting in the eastern Aleutian subduction zone, J. Geophys. Res., 103, 2597-2614, 1998.

Teske, A. and Nelson, D.: The Genera Beggiatoa and Thioploca, in: The Prokaryotes, edited by: Dworkin, M., Stanley, F., Rosenberg, E., Schleifer, K.-H., and Stackebrand, E., Springer-Verlag, Berlin, p. 784-810, 2006.

Tishchenko, P., Hensen, C., Wallmann, K., and Wong, C. S.: Calculation of the stability and solubility of methane hydrate in seawater, Chem. Geol., 219, 37-52, 2005.

Torres, M. E., McManus, J., Hammond, D. E., de Angelis, M. A., Heeschen, K. U., Colbert, S. L., Tryon, M. D., Brown, K. M., and Suess, E.: Fluid and chemical fluxes in and out of sediments hosting methane hydrate deposits on Hydrate Ridge, OR, I: Hydrological provinces, Earth Planet. Sci. Lett., 201, 525-540, 2002.

Treude, T., Boetius, A., Knittel, K., Wallmann, K., and Jørgensen, B. B.: Anaerobic oxidation of methane above gas hydrates at Hydrate Ridge, NE Pacific Ocean, Mar. Ecol. Prog. Ser., 264, 1-14, 2003.

Tryon, M. D., Brown, K. M., Torres, M. E., Trehu, A. M., McManus, J., and Collier, R. W.: Measurements of transience and downward fluid flow near episodic methane gas vents, Hydrate Ridge, Cascadia, Geology, 27, 1075-1078, 1999.

Tryon, M. D., Brown, K. M., and Torres, M. E.: Fluid and chemical flux in and out of sediments hosting methane hydrate deposits on Hydrate Ridge, OR, II: Hydrological processes, Earth Planet. Sci. Lett., 201, 541-557, 2002. van Dover, C. L., Aharon, P., Bernhard, J. M., Caylor, E., Doerries, M., Flickinger, W., Gilhooly, W., Goffredi, S. K., Knick, K. E., Macko, S. A., Rapoport, S., Raulfs, E. C., Ruppel, C., Salerno, J. L., Seitz, R. D., Sen Gupta, B. K., Shank, T., Turnipseed, M., and Vrijenhoek, R.: Blake Ridge methane seeps: characterization of a soft-sediment, chemosynthetically based ecosystem, Deep Sea Res. Part I, 50, 281-300, 2003.

von Rad, U., Schulz, H., Khan, A. A., Ansari, M., Berner, U., Cepek, P., Cowie, G., Dietrich, P., Erlenkeuser, H., Geyh, M., Jennerjahn, T., Lückge, A., Marchig, V., Riech, V., Rösch, H., Schäfer, P., Schulte, S., Sirocko, F., Tahir, M., and Weiss, W.: Sampling the oxygen minimum zone off Pakistan: glacialinterglacial variations of anoxia and productivity (preliminary results, Sonne 90 cruise), Mar. Geol., 125, 7-19, 1995.

von Rad, U., Rösch, H., Berner, U., Geyh, M., Marchig, V., and Schulz, H.: Authigenic carbonates derived from oxidized methane vented from the Makran accretionary prism off Pakistan, Mar. Geol., 136, 55-77, 1996.

von Rad, U., Berner, U., Delisle, G., Doose-Rolinski, H., Fechner, N., Linke, P., Lückge, A., Roeser, H. A., Schmaljohann, R., Wiedicke, M., Parties, S. S., Parties, S. S., Block, M., Damm, V., Erbacher, J., Fritsch, J., Harazim, B., Poggenburg, J., Scheeder, G., Schreckenberger, B., von Mirbach, N., Drews, M., Walter, S., Ali Khan, A., Inam, A., Tahir, M., Tabrez, A. R., Cheema, A. H., Pervaz, M., and Ashraf, M.: Gas and fluid venting at the Makran accretionary wedge off Pakistan, Geo-Mar. Lett., 20, 10 19, 2000.

Wallace, P. J., Dickens, G. R., Paull, C. K., and Ussler, W.: Effects of core retrieval and degassing on the carbon isotope composition of methane in gas hydrate and free-gas bearing sediments from the Blake Ridge, Proceedings of the Ocean Drilling Program, Scientific Results, 164, 101-112, 2000.

Wallmann, K., Linke, P., Suess, E., Bohrmann, G., Sahling, H., Schlüter, M., Dählmann, A., Lammers, S., Greinert, J., and von Mirbach, N.: Quantifying fluid flow, solute mixing, and biogeochemical turnover at cold vents of the eastern Aleutian subduction zone, Geochim. Cosmochim. Acta, 61, 5209-5219, 1997.

Wallmann, K., Drews, M., Aloisi, G., and Bohrmann, G.: Methane discharge into the Black Sea and the global ocean via fluid flow through submarine mud volcanoes, Earth Planet. Sci. Lett., 248, 545-560, 2006.

Wenzhöfer, F., Adler, M., Kohls, O., Hensen, C., Strotmann, B., Boehme, S., and Schulz, H. D.: Calcite dissolution driven by benthic mineralization in the deep-sea: in situ measurements of $\mathrm{Ca}^{2+}, \mathrm{pH}, \mathrm{pCO}_{2}$ and $\mathrm{O}_{2}$, Geochim. Cosmochim. Acta, 65, 2677-2690, 2001.

Wyrtki, K.: Physical oceanography of the Indian Ocean, in: The biology of the Indian Ocean. Ecological Studies, edited by: Zeitschel, B., Springer Verlag, Berlin, p. 18-36, 1973. 